\title{
Synthesis, solid state structure and spectro-electrochemistry of ferrocene-ethynyl phosphine and phosphine oxide transition metal complexes
}

\author{
Alexander Jakob ${ }^{a}$, Petra Ecorchard ${ }^{a}$, Michael Linseis ${ }^{b}$, Rainer F. Winter ${ }^{b}$, Heinrich Lang ${ }^{\mathrm{a}, *}$ \\ ' Technische Universität Chemnitz, Fakultät für Naturwissenschaften, Institut für Chemie, Lehrstuhl für Anorganische Chemie, Straße der Nationen 62,09111 Chemnitz, Germany \\ ${ }^{\mathrm{b}}$ Universität Regensburg, Institut für Anorganische Chemie, Universitätsstraße 31, 93040 Regensburg, Germany
}

\begin{abstract}
The synthesis of ferrocene-ethynyl phosphine platinum dichloride complexes based on $(\mathrm{FcC} \equiv \mathrm{C})_{n} \mathrm{Ph}_{3-n} \mathrm{P}$ $\left(\mathbf{1 a}, n=1 ; \mathbf{1 b}, n=2 ; 1 \mathbf{c}, n=3 ; \mathrm{Fc}=\right.$ ferrocenyl, $\left.\left(\eta^{5}-\mathrm{C}_{5} \mathrm{H}_{5}\right)\left(\eta^{5}-\mathrm{C}_{5} \mathrm{H}_{4}\right) \mathrm{Fe}\right)$ is described. Air-oxidation of $1 \mathrm{c}$ afforded $(\mathrm{FcC} \equiv \mathrm{C})_{3} \mathrm{P}=0$ (6). Treatment of $\mathbf{1 a}-\mathbf{1 c}$ with $\left[(\mathrm{PhC} \equiv \mathrm{N})_{2} \mathrm{PtCl}_{2}\right]$ (2) or $[($ tht $) \mathrm{AuCl}]$ (tht $=$ tetrahydrothiophene) (7), respectively, gave the heterometallic transition complexes cis-[((FcC $\equiv \mathrm{C})_{n}$ $\left.\left.\mathrm{Ph}_{3-n} \mathrm{P}\right)_{2} \mathrm{PtCl}_{2}\right](3 \mathbf{a}, n=1 ; \mathbf{3 b}, n=2 ; \mathbf{3 c}, n=3)$ or $\left[\left((\mathrm{FCC}=\mathrm{C})_{n} \mathrm{PPh}_{3-n}\right) \mathrm{AuCl}\right](\mathbf{8 a}, n=1 ; \mathbf{8 b}, n=2)$. Further treatment of these molecules with $\mathrm{HC} \equiv \mathrm{CMc}\left(\mathbf{4 a}, \mathrm{Mc}=\mathrm{Fc} ; \mathbf{4 b}, \mathrm{Mc}=\mathrm{Rc}=\left(\eta^{5}-\mathrm{C}_{5} \mathrm{H}_{5}\right)\left(\eta^{5}-\mathrm{C}_{5} \mathrm{H}_{4}\right) \mathrm{Ru}\right)$ in the presence of [CuI] produced trans-[((FCC $\left.\left.\equiv C) \mathrm{Ph}_{2} \mathrm{P}\right)_{2} \mathrm{Pt}(\mathrm{C} \equiv \mathrm{CFC})_{2}\right]$ (5) (reaction of 3a with 4a) and $\left[(\mathrm{FcC} \equiv \mathrm{C})_{n} \mathrm{Ph}_{3-n} \mathrm{PAuC} \equiv \mathrm{CMc}\right](n=1: 9 \mathrm{a}, \mathrm{Mc}=\mathrm{Fc} ; \mathbf{9 b}, \mathrm{Mc}=\mathrm{Rc} ; n=2: 11 \mathrm{a}, \mathrm{Mc}=\mathrm{Fc} ; \mathbf{1 1 b}, \mathrm{Mc}=\mathrm{Rc})($ reaction of $4 a, 4 b$ with $8 \mathbf{a}, 8 \mathbf{b})$, respectively.

The structures of $3 a, 5,6,8,9 a$, and $9 b$ in the solid state were established by single-crystal X-ray structure analysis. The main characteristic features of these molecules are the linear phosphorus-gold-acetylide arrangements, the tetra-coordination at phosphorus and the square-planar surrounding at platinum.

The electrochemical and spectro-electrochemical behavior of complexes $\mathbf{5}, \mathbf{8 a}, \mathbf{9 a}, \mathbf{9 b}$ and $\left[\left(\mathrm{Ph}_{3} \mathrm{P}\right) \mathrm{AuC} \equiv \mathrm{CFc}\right]$ was investigated in the UV/Vis/NIR. Near IR bands that are likely associated with charge transfer from the $\left((\mathrm{FCC} \equiv \mathrm{C}) \mathrm{Ph}_{2} \mathrm{P}\right)_{2} \mathrm{Pt}$ or the $\left((\mathrm{FCC} \equiv \mathrm{C})_{n} \mathrm{Ph}_{3-n} \mathrm{P}\right) \mathrm{Au}(n=0,1)$ moieties appear upon oxidation of the $\sigma$-bonded ferrocene-ethynyl groups. These bands undergo a (stepwise) blue shift as ferrocene-ethynyl substituents on the phosphine coligands are oxidized.
\end{abstract}

\section{Introduction}

Ferrocene is an exceptional building block to be incorporated in multimetallic transition metal complexes since it can act as a redox-label, one-electron reservoir and at the same time is a very robust compound [1]. Such assemblies provide interesting electronic, optical and/or magnetic properties $[1,2]$. One class of electron-rich sandwich complexes are ferrocenes containing exocyclic phosphine, phosphine chalcogenide or amine groups [3]. The electrochemically best studied candidate of this class of compounds is (diphenylphosphino)ferrocene, $\quad \mathrm{Ph}_{2} \mathrm{PFC} \quad\left(\mathrm{Fc}=\left(\eta^{5}-\mathrm{C}_{5} \mathrm{H}_{5}\right)\left(\eta^{5}-\right.\right.$ $\left.\mathrm{C}_{5} \mathrm{H}_{4}\right) \mathrm{Fe}$ ) [3]. Very recently, Kirss and Geiger reported about the anodic electrochemistry of phosphines and phosphine chalcogenides containing two or three ferrocenyl organometallic entities in weakly nucleophilic electrolytes [3]. In addition to the study of their redox behavior species of this kind are interesting building blocks for coordination compounds of higher nuclearity, due to the presence of the phosphine unit. Coordinative and/or covalent

\footnotetext{
* Corresponding author. Tel.: +49 371531 21210; fax: +49 37153121219 E-mail address: heinrich.lang@chemie.tu-chemnitz.de (H. Lang).
}

linking of such a modularly constructed sandwich building block allows the synthesis of heteromultimetallic ferrocenyl-containing assemblies in which the appropriate transition metal atoms are connected by carbon-rich organic and/or inorganic bridging moieties [4]. Promising members of this family of compounds are the (ferrocene-ethynyl)phosphines $(\mathrm{FcC} \equiv \mathrm{C})_{n} \mathrm{Ph}_{3-n} \mathrm{P} \quad(n=1,2,3)$, a hitherto only barely described class of molecules [5].

We report here on the synthesis, properties and the characterization of several platinum and gold (ferrocene-ethynyl)phosphine complexes. The spectro-electrochemical behavior of some trimetallic gold complexes and of a pentametallic platinum complex is also reported.

\section{Results and discussion}

The synthesis of transition metal complexes in which $(\mathrm{FCC} \equiv \mathrm{C})_{n} \mathrm{Ph}_{3-n} \mathrm{P}$ units $(\mathbf{1} \mathbf{a}, n=1 ; \mathbf{1} \mathbf{b}, n=2 ; \mathbf{1 c}, n=3)$ are connected to a $\mathrm{PtCl}_{2}$ core, as given in cis- $\left[\left((\mathrm{FcC} \equiv \mathrm{C})_{n} \mathrm{Ph}_{3-n} \mathrm{P}_{2} \mathrm{PtCl}_{2}\right](n=1,3 \mathrm{a}\right.$; $n=2,3 \mathbf{b} ; n=3,3 \mathbf{c})$, is presented in Scheme 1 .

Reacting two equivalents of $\mathbf{1 a - 1 c}$ with $\left[(\mathrm{PhC} \equiv \mathrm{N})_{2} \mathrm{PtCl}_{2}\right]$ (2) produced the multi(ferrocene-ethynyl)phosphine platinum(II) 


$$
\begin{aligned}
& 2(\mathrm{FcC} \equiv \mathrm{C})_{n} \mathrm{Ph}_{3 \cdot n} \mathrm{P}+\left[(\mathrm{PhCN})_{2} \mathrm{PtCl}_{2}\right] \frac{\mathrm{CH}_{2} \mathrm{Cl}_{2}}{-2 \mathrm{PhC} \mathrm{N}} \text { cis- }\left[\left((\mathrm{FcC} \equiv \mathrm{C})_{n} \mathrm{Ph}_{3-n} \mathrm{P}\right)_{2} \mathrm{PtCl}_{2}\right] \\
& \begin{array}{l}
1 \mathrm{a}, n=1 \\
1 \mathrm{~b}, \mathrm{n}=2
\end{array} \\
& \begin{array}{l}
1 \mathrm{~b}, n=2 \\
1 \mathrm{c}, \mathrm{n}=3
\end{array} \\
& \mathrm{Fc}= \\
& 3 c, n=3
\end{aligned}
$$

Scheme 1. Synthesis of phosphine platinum complexes $\mathbf{3 a - 3 c}$.

chlorides 3a-3c in dichloromethane at ambient temperature in high yield. They can easily be isolated as analytically pure samples upon concentration of the reaction solutions and addition of petroleum ether, whereby the title compounds precipitate as orange solids. Single crystals of $3 \mathrm{c}$ could be grown by diffusion of $n$-pentane into dichloromethane solutions containing $3 \mathrm{c}$ at $25^{\circ} \mathrm{C}$.

The structure of $\mathbf{3 c}$ in the solid state is depicted in Fig. 1. Relevant bond distances $(\AA)$ and angles $\left(^{\circ}\right)$ are listed in Table 1 . The crystal and structure refinement data are presented in Table 6 (Section 4).

Complex $3 c$ crystallized in the monoclinic space group $P \overline{1}$. The structure of $\mathbf{3 c}$ in the solid state shows a somewhat distorted square-planar coordination geometry at Pt1 with cis-oriented $(\mathrm{FcC} \equiv \mathrm{C})_{3} \mathrm{P}$ units (r.m.s. deviation of fitted atoms $0.0625 \AA$ ). The angles $\mathrm{P} 1-\mathrm{Pt} 1-\mathrm{Cl} 2$ and $\mathrm{P} 2-\mathrm{Pt} 1-\mathrm{Cl} 1$ in $3 \mathrm{c}$ are almost linear at 175.58(4) and $173.35(4)^{\circ}$. The Pt-P and Pt-Cl separations (Fig. 1) agree well with those bond lengths reported for other chloro-phos-

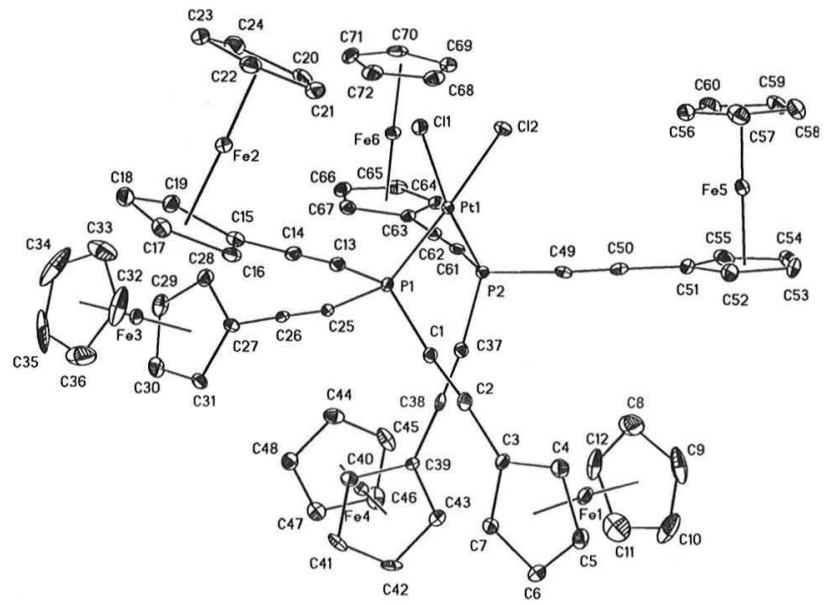

\begin{tabular}{|c|c|c|c|}
\hline \multicolumn{4}{|l|}{ Bond distances } \\
\hline $\mathrm{Pt} 1-\mathrm{Cl} 1$ & $2.3362(10)$ & $\mathrm{C} 13-\mathrm{C} 14$ & $1.192(5)$ \\
\hline $\mathrm{Pt} 1-\mathrm{Cl} 2$ & $2.3501(11)$ & $\mathrm{C} 25-\mathrm{C} 26$ & $1.198(5)$ \\
\hline Pt1-P1 & $2.2152(11)$ & $\mathrm{C} 37-\mathrm{C} 38$ & $1.198(5)$ \\
\hline $\mathrm{Pt} 1-\mathrm{P} 2$ & $2.2290(11)$ & C49-C50 & $1.191(5)$ \\
\hline $\mathrm{C} 1-\mathrm{C} 2$ & $1.194(5)$ & C61-C62 & $1.192(5)$ \\
\hline \multicolumn{4}{|l|}{ Bond angles } \\
\hline $\mathrm{P} 1-\mathrm{Pt} 1-\mathrm{Cl} 2$ & $175.58(4)$ & $\mathrm{Pt}-\mathrm{P} 2-\mathrm{C} 61$ & $112.38(14)$ \\
\hline $\mathrm{P} 2-\mathrm{Pt} 1-\mathrm{Cl} 1$ & $173.35(4)$ & $\mathrm{P} 1-\mathrm{C} 1-\mathrm{C} 2$ & $174.6(4)$ \\
\hline $\mathrm{P} 1-\mathrm{Pt} 1-\mathrm{P} 2$ & $93.85(4)$ & $\mathrm{P} 1-\mathrm{C} 13-\mathrm{C} 14$ & $169.8(4)$ \\
\hline $\mathrm{Pt1}-\mathrm{P} 1-\mathrm{C} 1$ & $115.28(14)$ & $\mathrm{P} 1-\mathrm{C} 25-\mathrm{C} 26$ & $167.6(4)$ \\
\hline $\mathrm{Pt} 1-\mathrm{P} 1-\mathrm{C} 13$ & $118.50(14)$ & $\mathrm{P} 2-\mathrm{C} 37-\mathrm{C} 38$ & $173.3(4)$ \\
\hline $\mathrm{Pt} 1-\mathrm{P} 1-\mathrm{C} 25$ & $110.74(14)$ & $P 2-C 49-C 50$ & $172.3(4)$ \\
\hline $\mathrm{Pt} 1-\mathrm{P} 2-\mathrm{C} 37$ & $118.25(14)$ & $\mathrm{P} 2-\mathrm{C} 61-\mathrm{C} 62$ & $171.7(4)$ \\
\hline Pt-P2-C49 & $110.61(14)$ & & \\
\hline
\end{tabular}

Fig. 1. ORTEP diagram (50\% probability level) of $3 \mathrm{c}$ with the atom-numbering scheme. (Hydrogen atoms are omitted for clarity.)

Table 1

Selected bond distances $(\AA)$ and angles $\left(^{\circ}\right)$ of complex 3c. phine platinum units in which the $\mathrm{Pt}-\mathrm{Cl}$ bonds are likewise trans positioned to a phosphorus donor atom of high trans-influence [6]. The phosphorus-carbon distances (1.726(4)-1.752(4) $\AA$ ) as well as the $C \equiv C$ bond lengths (1.191(5)-1.198(5) $\AA$ ) are in the typical range for this type of fragments [5,7]. As is characteristic of other ferrocene complexes the Fe-D separations ( $D=$ centroid of $\mathrm{C}_{5} \mathrm{H}_{5}$ and $\mathrm{C}_{5} \mathrm{H}_{4}$ units) range from 1.6406(2) to 1.6609(2) $\AA$ [8]. Based on the torsion angles $\mathrm{C}_{\mathrm{sp}}-\mathrm{C}_{\mathrm{Cp}}-\mathrm{Fe}-\mathrm{C}_{\mathrm{Cp}^{\prime}}$, whereby $\mathrm{C}_{\mathrm{Cp}^{\prime}}$ was selected for the minimum resulting angle, eclipsed (torsion angle: $\mathrm{C} 14-\mathrm{C} 15-\mathrm{Fe} 2-\mathrm{C} 20=7.7(4)^{\circ} . \quad \mathrm{C} 26-\mathrm{C} 27-\mathrm{Fe} 3-\mathrm{C} 32=8.5(4)^{\circ}, \quad \mathrm{C} 50-$ $\mathrm{C} 51-\mathrm{Fe} 5-\mathrm{C} 56=9.0(4)^{\circ}$, and $\left.\mathrm{C} 62-\mathrm{C} 63-\mathrm{Fe} 6-\mathrm{C} 68=10.5(4)^{\circ}\right)$ and staggered (torsion angle: $\mathrm{C} 2-\mathrm{C} 3-\mathrm{Fe} 1-\mathrm{C} 8=20.8(4)^{\circ}$ and $\mathrm{C} 38-\mathrm{C} 39-$ $\left.\mathrm{Fe} 4-\mathrm{C} 44=18.6(4)^{\circ}\right)$ conformations are typical.

The ${ }^{1} \mathrm{H},{ }^{13} \mathrm{C}\left\{{ }^{1} \mathrm{H}\right\},{ }^{31} \mathrm{P}\left\{{ }^{1} \mathrm{H}\right\}$ NMR and IR spectroscopic data are in agreement with the composition of the appropriate complexes and show no distinctive features compared with the systems discussed earlier (Section 4). The $J\left({ }^{31} \mathrm{P}-{ }^{195} \mathrm{Pt}\right)$ coupling constants of 3760 (3a), 3886 (3b), and $4029 \mathrm{~Hz}$ (3c) found in the ${ }^{31} \mathrm{P}\left\{{ }^{1} \mathrm{H}\right\}$ NMR spectra confirm that cis-configurated platinum complexes were formed [5,9]. X-ray single-crystal structure determination of $\mathbf{3 c}$ confirms this structural arrangement (vide supra).

Diphosphine platinum dichloride complexes are known to react with 1-alkynes to produce (bis)alkynyl complexes [10]. Thus, treatment of 3a with an excess of $\mathrm{HC} \equiv \mathrm{CFc}(\mathbf{4 a})$ in the presence of [CuI] in a diisopropylamine solution produced with concomitant precipitation of $\left[\mathrm{H}_{2} \mathrm{~N}^{i} \mathrm{Pr}_{2}\right] \mathrm{Cl}$, orange trans- $\left.\left[(\mathrm{FcC} \equiv \mathrm{C}) \mathrm{Ph}_{2} \mathrm{P}\right)_{2} \mathrm{Pt}(\mathrm{C} \equiv \mathrm{CFc})_{2}\right]$ (5) in a 75\% isolated yield (Reaction (1)).

$$
\begin{aligned}
& \text { cis- }\left[\left((\mathrm{FcC} \equiv \mathrm{C}) \mathrm{Ph}_{2} \mathrm{P}\right)_{2} \mathrm{PtCl}_{2}\right] \underset{\mathrm{HN}^{\prime} \mathrm{Pr}_{2} \text {, [Cul] }}{2 \mathrm{HC} \equiv \mathrm{CFc}(4 \mathrm{a})} \rightarrow \text { trans- }\left[\left((\mathrm{FcC} \equiv \mathrm{C}) \mathrm{Ph}_{2} \mathrm{P}\right)_{2} \mathrm{Pt}(\mathrm{C} \equiv \mathrm{CFc})_{2}\right] \\
& \text { 3a } \\
& F c=\frac{1}{\mathrm{Fe}}
\end{aligned}
$$

Most noteworthy in the IR spectrum of $\mathbf{5}$ is the appearance of two well-separated $\mathrm{C} \equiv \mathrm{C}$ stretching bands at 2162 and $2180 \mathrm{~cm}^{-1}$ which can be assigned to the $\mathrm{FCC} \equiv \mathrm{CPt}$ and $(\mathrm{FcC} \equiv \mathrm{C}) \mathrm{Ph}_{2} \mathrm{P}$ moieties (Section 4 ).

In the ${ }^{31} \mathrm{P}\left\{{ }^{1} \mathrm{H}\right\}$ NMR spectrum of $\mathbf{5}$ a sharp singlet is observed at $-7.3 \mathrm{ppm}$. Due to the coupling of the ${ }^{31} \mathrm{P}$ nuclei with the ${ }^{195} \mathrm{Pt}$ isotope a $J\left({ }^{31} \mathrm{P}-{ }^{195} \mathrm{Pt}\right)$ coupling constant of $2765 \mathrm{~Hz}$ is found, which proves that an isomerization from cis-3a to trans-5 has taken place [11]

Single-crystal X-ray structure analysis was performed to confirm the molecular structure of $\mathbf{5}$ in the solid state. A view of this molecule is shown in Fig. 2, while selected bond distances $(\AA)$ and angles $\left({ }^{\circ}\right)$ are listed in Table 2 . The crystal and structure refinement data are summarized in Table 6 (Section 4).

The platinum metal atom is held in a distorted square-planar environment (all atoms are perfectly in-plane) with the coordinated $(\mathrm{FcC} \equiv \mathrm{C}) \mathrm{Ph}_{2} \mathrm{P}$ units in a trans-position to each other (Fig. 2) which is in accord with findings for other bis(alkynyl) complexes of monodentate phosphines [12]. The platinum-carbon and platinum-phosphorus separations (Fig. 2) are within the range of reported Pt-P and Pt-C bonds [12]. In addition, the carbon-carbon distances of the appropriate acetylide ligands are typical of this type of structural building blocks (Fig. 2) [12].

While molecules 1a-1c are fairly stable in the solid state, they slowly undergo oxidation at the phosphorus atom on exposure to air to give the respective phosphine oxides $(\mathrm{FCC} \equiv \mathrm{C})_{n} \mathrm{Ph}_{3-n} \mathrm{P}=\mathrm{O}$ (Section 4). Due to the superior electron richness $1 \mathrm{c}$ is easier oxidized than $\mathbf{1 a}$ and $\mathbf{1 b}$. Phosphine $\mathbf{1 c}$ is thus always contaminated with trace amounts of $(\mathrm{FCC} \equiv \mathrm{C})_{3} \mathrm{P}=\mathrm{O}(\mathbf{6})$. This means that the more ferrocene-ethynyl moieties are present, the more reactive the complexes are. Heating $\mathbf{1 c}$ in tetrahydrofuran and bubbling air 


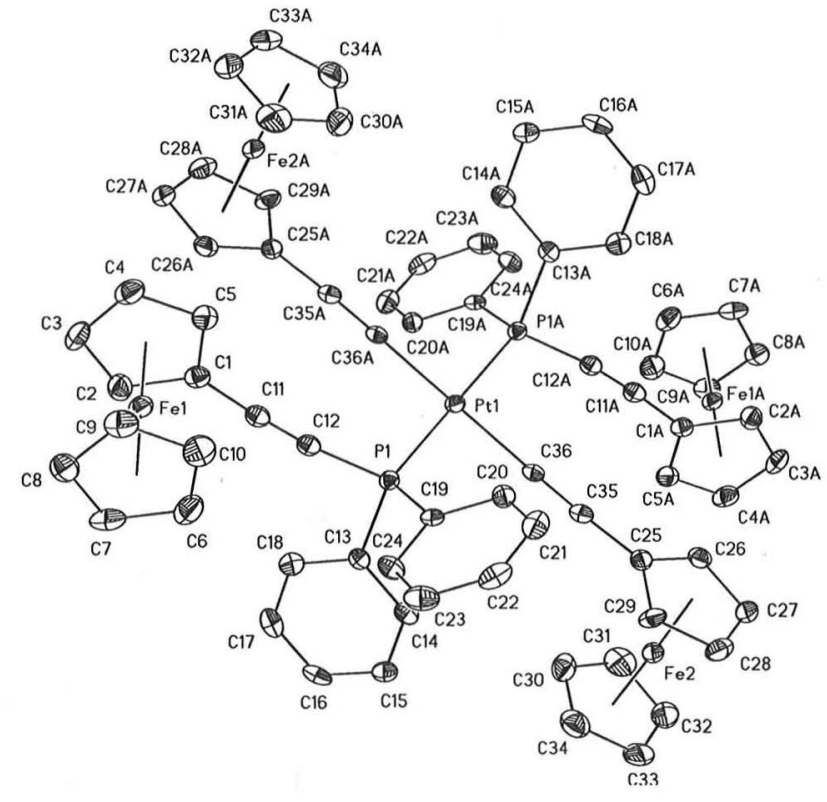

Fig. 2. ORTEP diagram ( $50 \%$ probability level) of $\mathbf{5}$ with the atom-numbering scheme. (Hydrogen atoms and the solvent molecule $\mathrm{CH}_{2} \mathrm{Cl}_{2}$ are omitted for clarity.)

Table 2

Selected bond distances $(\AA)$ and angles $\left(^{\circ}\right)$ of complexes 5 and $\mathbf{6}$.

\begin{tabular}{|c|c|c|c|}
\hline 5 & & 6 & \\
\hline \multicolumn{4}{|l|}{ Bond distances } \\
\hline $\mathrm{Pt} 1-\mathrm{P} 1$ & $2.2923(9)$ & P1-O1 & $1.4685(16)$ \\
\hline Pt1-C36 & $2.002(3)$ & $\mathrm{P} 1-\mathrm{C} 12$ & $1.7431(18)$ \\
\hline $\mathrm{P} 1-\mathrm{C} 12$ & $1.753(4)$ & $\mathrm{P} 1-\mathrm{C} 24$ & $1.7537(19)$ \\
\hline $\mathrm{C} 11-\mathrm{C} 12$ & $1.196(5)$ & P1-C36 & $1.7452(18)$ \\
\hline \multirow[t]{3}{*}{$\mathrm{C} 35-\mathrm{C} 36$} & $1.203(5)$ & $\mathrm{C} 11-\mathrm{C} 12$ & $1.207(3)$ \\
\hline & & $\mathrm{C} 23-\mathrm{C} 24$ & $1.203(3)$ \\
\hline & & $\mathrm{C} 35-\mathrm{C} 36$ & $1.204(3)$ \\
\hline \multicolumn{4}{|l|}{ Bond angles } \\
\hline P1-Pt1-C36 & $89.08(10)$ & $\mathrm{C} 11-\mathrm{C} 12-\mathrm{P} 1$ & $171.17(16)$ \\
\hline $\mathrm{Pt} 1-\mathrm{P} 1-\mathrm{C} 12$ & $115.66(12)$ & $\mathrm{C} 23-\mathrm{C} 24-\mathrm{P} 1$ & $177.32(17)$ \\
\hline Pt1-P1-C13 & 114.99 & $\mathrm{C} 35-\mathrm{C} 36-\mathrm{P} 1$ & $168.67(16)$ \\
\hline Pt1-P1C19 & $116.60(12)$ & $\mathrm{C} 12-\mathrm{P} 1-\mathrm{C} 24$ & $103.38(8)$ \\
\hline $\mathrm{P} 1-\mathrm{C} 12-\mathrm{C} 11$ & $1714(3)$ & $\mathrm{C} 24-\mathrm{P} 1-\mathrm{C} 36$ & $101.94(9)$ \\
\hline $\mathrm{C} 1-\mathrm{C} 11-\mathrm{C} 12$ & $176.6(4)$ & $\mathrm{C} 12-\mathrm{P} 1-\mathrm{C} 36$ & $105.74(9)$ \\
\hline $\mathrm{Pt} 1-\mathrm{C} 36-\mathrm{C} 35$ & $178.1(3)$ & $\mathrm{C} 12-\mathrm{P} 1-\mathrm{O} 1$ & $115.26(9)$ \\
\hline \multirow[t]{2}{*}{$\mathrm{C} 25-\mathrm{C} 35-\mathrm{C} 36$} & $175.9(4)$ & C24-P1-O1 & $114.84(9)$ \\
\hline & & $\mathrm{C} 36-\mathrm{P} 1-01$ & $114.18(9)$ \\
\hline
\end{tabular}

through the reaction solution gave orange $\mathbf{6}$ in quantitative yield (Reaction (2)).

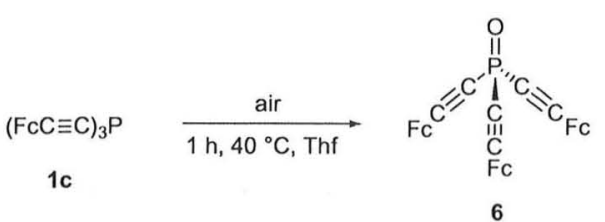

Compound 6 was characterized by elemental analysis, IR and NMR spectroscopy. Characteristic features in the IR spectrum of this compound are the $\mathrm{C} \equiv \mathrm{C}$ stretching vibration at $2150 \mathrm{~cm}^{-1}$ and the $v_{(\mathrm{P}=0)}$ absorption at $1254 \mathrm{~cm}^{-1}$ [13]. The progress of the oxidation of $1 \mathrm{c}$ can be monitored by the disappearance of the ${ }^{31} \mathrm{P}$ NMR signal at $-88.9 \mathrm{ppm}$ (1c) [5] and the appearance of a new signal at lower field (-66.8 ppm). The key spectroscopic ${ }^{1} \mathrm{H}$ NMR feature is that the protons of the ferrocenyl $\mathrm{C}_{5} \mathrm{H}_{4}$ unit appear as two separated pseudo-triplets at ca. 4.3 and $4.6 \mathrm{ppm}$ with $J_{\mathrm{HH}}$ coupling constants of $1.9 \mathrm{~Hz}$. The resonance signal for the $\mathrm{C}_{5} \mathrm{H}_{5}$ protons is found at $4.25 \mathrm{ppm}$.

The identity of $\mathbf{6}$ was further confirmed by a single-crystal X-ray diffraction study. A view of the molecule is given in Fig. 3. Selected bond distances $(\AA)$ and angles $\left(^{\circ}\right)$ are given in Table 2 , while the crystal and structure refinement data are presented in Table 6 (Section 4).

The overall structure of $\mathbf{6}$ is similar to those of related structurally characterized ethynyl-functionalized phosphines and ferrocenes with a pseudo-tetrahedral surrounding at the phosphorus atom [14]. Metrical parameters of molecule $\mathbf{6}$ are similar related to those reported previously for comparable molecules [14]. The phosphorus-carbon distances in 6 are 1.7431(18) (P1-C12), $1.7537(19)$ ( $\mathrm{P} 1-\mathrm{C} 24)$, and $1.7452(18) \AA$ (P1-C36) indicating the higher $s$ orbital contribution of the phosphorus-acetylide $\mathrm{P}-\mathrm{C}$ bond, when compared with the $\mathrm{P}-\mathrm{C}_{\text {phenyl }}$ unit. The cyclopentadienyl rings are rotated by $8.62,1.92$ and $0.55^{\circ}$ to each other which is in accord with an almost eclipsed conformation.

The ferrocene-ethynyl phosphine complexes 1a-1c independently synthesized by Baumgartner et al. [5a] and our group. [5b] possess a lone pair of electrons at the phosphorus atom and hence, should coordinate to 14-16 valence electron complex fragments to form molecules of higher nuclearity. Exemplarily, trimetallic $\mathrm{Fe}-\mathrm{Au}-\mathrm{M}$ complexes $(\mathrm{M}=\mathrm{Fe}, \mathrm{Ru})$ of composition $\left[\left((\mathrm{FcC} \equiv \mathrm{C}) \mathrm{Ph}_{2} \mathrm{P}\right) \mathrm{AuC} \equiv \mathrm{CMc}\right] \quad\left(\mathbf{9 a}, \quad \mathrm{Mc}=\left(\eta^{5}-\mathrm{C}_{5} \mathrm{H}_{5}\right)\left(\eta^{5}-\mathrm{C}_{5} \mathrm{H}_{4}\right) \mathrm{Fe} ; \mathbf{9 b}\right.$, $\left.\mathrm{MC}=\left(\eta^{5}-\mathrm{C}_{5} \mathrm{H}_{5}\right)\left(\eta^{5}-\mathrm{C}_{5} \mathrm{H}_{4}\right) \mathrm{Ru}\right)$ were accessible in a consecutive reaction sequence by using $(\mathrm{FCC} \equiv \mathrm{C}) \mathrm{Ph}_{2} \mathrm{P}(\mathbf{1} \mathbf{a})$ as the key starting material (Scheme 2).

Compound $\mathbf{1 a}$ reacts with [(tht) $\mathrm{AuCl}]$ (tht $=$ tetrahydrothiophene) (7), whereby $1 \mathbf{a}$ is added in a $25 \%$ excess in tetrahydrofuran at $0{ }^{\circ} \mathrm{C}$ to give 8 a. After column chromatography followed by crystallization from dichloromethane- $n$-pentane mixtures molecule $8 \mathbf{a}$

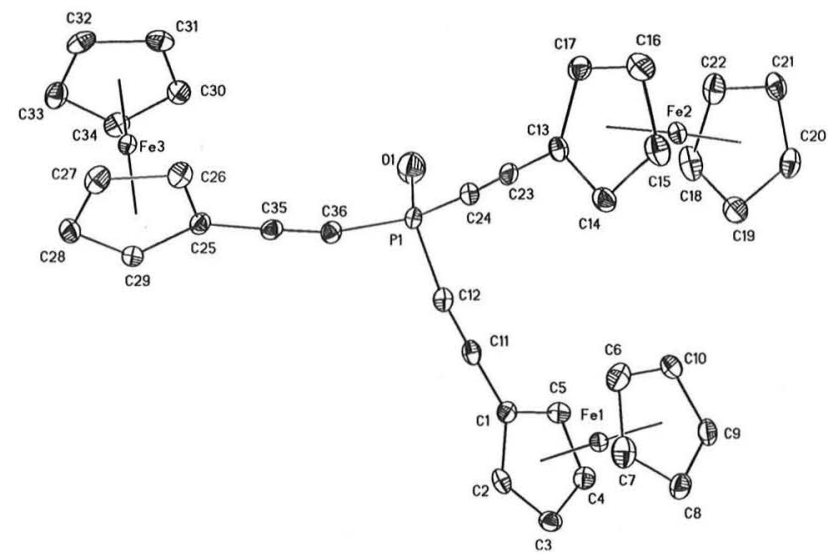

Fig. 3. ORTEP diagram ( $50 \%$ probability level) of $\mathbf{6}$ with the atom-numbering scheme. (Hydrogen atoms are omitted for clarity.)

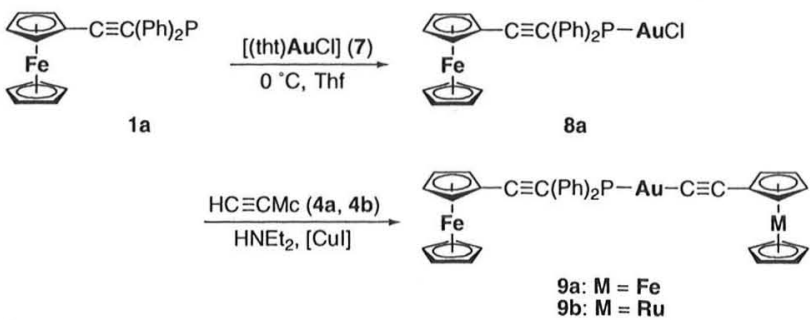

Scheme 2. Synthesis of $\mathbf{8 a}, \mathbf{9 a}$, and $\mathbf{9 b}$ from $\mathbf{1 a}$ (tht = tertralydrothiophene). 
could be isolated as an orange solid in $97 \%$ yield (Section 4 ). To introduce a further transition metal fragment, heterodimetallic $8 \mathrm{a}$ was treated with $\mathrm{HC} \equiv \mathrm{CMc}\left(\mathbf{4 a}, \mathrm{Mc}=\left(\eta^{5}-\mathrm{C}_{5} \mathrm{H}_{5}\right)\left(\eta^{5}-\mathrm{C}_{5} \mathrm{H}_{4}\right) \mathrm{Fe}\right.$; $\left.4 \mathrm{~b}, \mathrm{Mc}=\left(\eta^{5}-\mathrm{C}_{5} \mathrm{H}_{5}\right)\left(\eta^{5}-\mathrm{C}_{5} \mathrm{H}_{4}\right) \mathrm{Ru}\right)$ in diethylamine as solvent and in the presence of catalytic amounts of [CuI] (Scheme 2). Following the methodology reported by Vicente et al. orange $\mathbf{9 a}$ and $\mathbf{9 b}$ were obtained in high yields [15].

Complexes $8 \mathbf{a}, \mathbf{9 a}$, and $\mathbf{9 b}$ are, when compared with the starting material 1a, more difficult to dissolve. Complexes 9a and $\mathbf{9 b}$, for example, are only soluble in diethyl ether, tetrahydrofuran or dichloromethane.

The synthesis methodology used in the preparation of $\mathbf{9 a}$ and $\mathbf{9 b}$ should successfully be transferable to $(\mathrm{FcC} \equiv \mathrm{C})_{2} \mathrm{PhP}(\mathbf{1 b})$. Thus, this compound was subsequently reacted with [(tht)AuCl] (7) in a $25 \%$ excess of the phosphine to give the desired phosphine gold chloride coordination complex $\left[\left((\mathrm{FCC} \equiv \mathrm{C})_{2} \mathrm{PhP}\right) \mathrm{AuCl}\right](\mathbf{8 b})$ (Scheme 3$)$. Treatment of the latter molecule with $\mathrm{McC} \equiv \mathrm{CH}(\mathbf{4 a}, 4 \mathbf{b})$ produced $\left[\left((\mathrm{FCC} \equiv \mathrm{C})_{2} \mathrm{PhP}\right) \mathrm{AuC} \equiv \mathrm{CMC}\right]\left(\mathbf{1 1 a}, \mathrm{Mc}=\left(\eta^{5}-\mathrm{C}_{5} \mathrm{H}_{5}\right)\left(\eta^{5}-\mathrm{C}_{5} \mathrm{H}_{4}\right) \mathrm{Fe} ; \mathbf{1 1} \mathbf{b}\right.$, $\left.\mathrm{Mc}=\left(\eta^{5}-\mathrm{C}_{5} \mathrm{H}_{5}\right)\left(\eta^{5}-\mathrm{C}_{5} \mathrm{H}_{4}\right) \mathrm{Ru}\right)$. These compounds could, however, not be separated in pure form from the reaction mixtures.

The identities of $\mathbf{8 a}, \mathbf{8 b}, \mathbf{9 a}$, and $\mathbf{9 b}$ have been confirmed by elemental analysis, IR, ${ }^{1} \mathrm{H},{ }^{13} \mathrm{C}\left\{{ }^{1} \mathrm{H}\right\}$, and ${ }^{31} \mathrm{P}\left\{{ }^{1} \mathrm{H}\right\}$ NMR spectroscopy.

The consecutive preparation of higher nuclear heterometallic assemblies from $\mathbf{1 a}$ and $\mathbf{1 b}$ are confirmed by ${ }^{1} \mathrm{H}$ and ${ }^{13} \mathrm{C}\left\{{ }^{1} \mathrm{H}\right\}$ NMR spectroscopic studies, since after each individual synthesis step the newly introduced coordination or organometallic complex fragments can be detected (Section 4). The spectroscopic properties of all new complexes correlate with their formulation as di-, -tri- and tetrametallic transition metal systems showing the respective signal patterns for the organic units (Section 4).

The ${ }^{31} \mathrm{P}\left\{{ }^{1} \mathrm{H}\right\}$ NMR spectra of $\mathbf{8}$ and $\mathbf{9}$ indicate the presence of a single phosphorus environment with resonance signals at 1.9 (8a), ca. $15(9 a, 9 b)$, and $-37.5 \mathrm{ppm}(\mathbf{8 b})$. A shift to lower field occurs upon coordination of the phosphorus atom to a $\mathrm{AuCl}$ moiety as given in $\mathbf{8 a}$ and $\mathbf{8 b}$ [16]. Replacing the chloride ligand in $\mathbf{8 a}$ and $\mathbf{8 b}$ by a $\mathrm{C} \equiv$ CMc unit results in a further downfield shift (Section 4) which is typical for phosphine gold(I) acetylides [16].

Most characteristic in the IR spectra of $\mathbf{8 a}, \mathbf{8 b}$, and $\mathbf{9 a}$ is the appearance of only one $\mathrm{C} \equiv \mathrm{C}$ stretching vibration at ca. 2155 $\mathrm{cm}^{-1}$ independent of the appropriate substitution pattern. However, this absorption is shifted to ca. $2167 \mathrm{~cm}^{-1}$ when the gold(I)-bonded $\mathrm{FcC} \equiv \mathrm{C}$ unit is replaced by a ruthenocene acetylide moiety as given in $\mathbf{9 b}$. Only one $v_{\mathrm{C}=\mathrm{C}}$ band was found for the two different alkynyl entities, $\mathrm{PC} \equiv \mathrm{CFc}$ and $\mathrm{AuC} \equiv \mathrm{CFc}$, in the IR spectra of their coordination complexes.

In addition, the structures of $\mathbf{8 a}, \mathbf{9 a}$, and $\mathbf{9 b}$ in the solid state were established by single X-ray structure analysis, thus confirming the assignments made from spectroscopic analysis. Suitable single crystals of $\mathbf{8 a}, \mathbf{9 a}$, and $\mathbf{9 b}$ were obtained from slow vapor diffusion of $n$-pentane into a dichloromethane solution containing the appropriate transition metal complex at $25^{\circ} \mathrm{C}$. The molecular solid state structures of $\mathbf{8 a}, \mathbf{9 a}$, and $\mathbf{9 b}$ are shown in Figs. 4-6, while se-
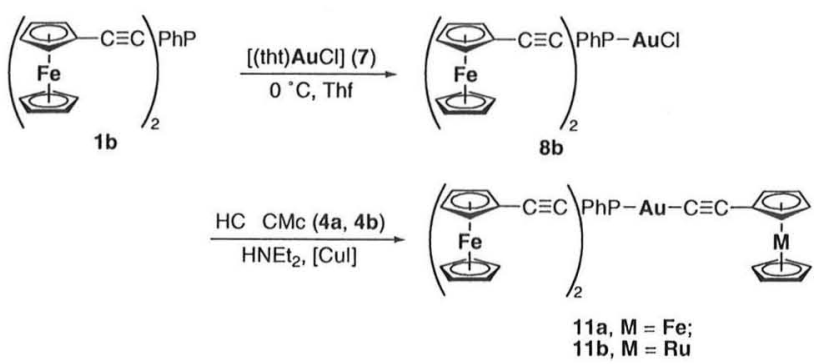

Scheme 3. Synthesis of heterobi- and -trimetallic 8b, 11a, and 11b, respectively. lected bond lengths $(\AA)$ and angles $\left(^{\circ}\right)$ are given in Table 3 . The crystal and structure refinement data for these species are presented in Table 7 (Section 4).

Complex 8a crystallized in the monoclinic space group $P 2_{1} / n$. The overall structural features of $\mathbf{8 a}$ are similar to those of related (diphenyl)ferrocene-ethynyl phosphine and gold(I)-chloridecontaining compounds with gold in a linear arrangement and phosphorus in a tetrahedral surrounding (Fig. 4). The cyclopentadienyl rings of the Fc entity are rotated by $5.8^{\circ}$ showing an almost eclipsed conformation. The Au1-Cl1 and Au1-P1 distances agree well with this type of bonds. [17] The same is true for the P1$\mathrm{C} 12, \mathrm{P} 1-\mathrm{C} 13$ and $\mathrm{P} 1-\mathrm{C} 19$ separations. The $\mathrm{P} 1-\mathrm{C} 12$ bond of $1.739(3) \AA$ is expectedly shorter than the respective $\mathrm{P} 1-\mathrm{C} 13$ $(1.815(3) \AA)$ and P1-C19 (1.810(3) $\AA$ ) distances (vide supra and Fig. 4) [17].

Molecules $9 \mathbf{a}$ and $\mathbf{9 b}$ crystallized in the monoclinic space groups $P 2_{1} / c$ (9a) and $P 2_{1} / a(9 \mathbf{b})$. In both complexes the gold(I) ion adopts the usual linear coordination [18]. The phosphorus atom is tetra-coordinated, whereby two positions are occupied by phenyl groups and the third and fourth coordination sites are occupied by a $\mathrm{C} \equiv \mathrm{CFc}$ and a $\mathrm{AuC} \equiv \mathrm{CFc}(\mathbf{9 a})$ or $\mathrm{AuC} \equiv \mathrm{CRc}(\mathbf{9 b})$ unit (Figs. 5 and 6). This coordination geometry is representative for phosphines coordinated to a transition metal complex fragment

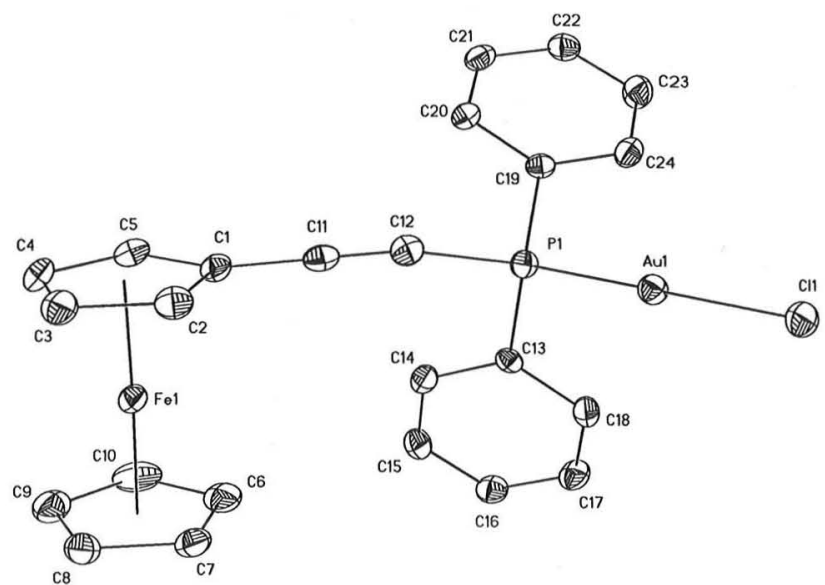

Fig. 4. ORTEP diagram (50\% probability level) of 8 a with the atom-numbering scheme. (Hydrogen atoms are omitted for clarity.)

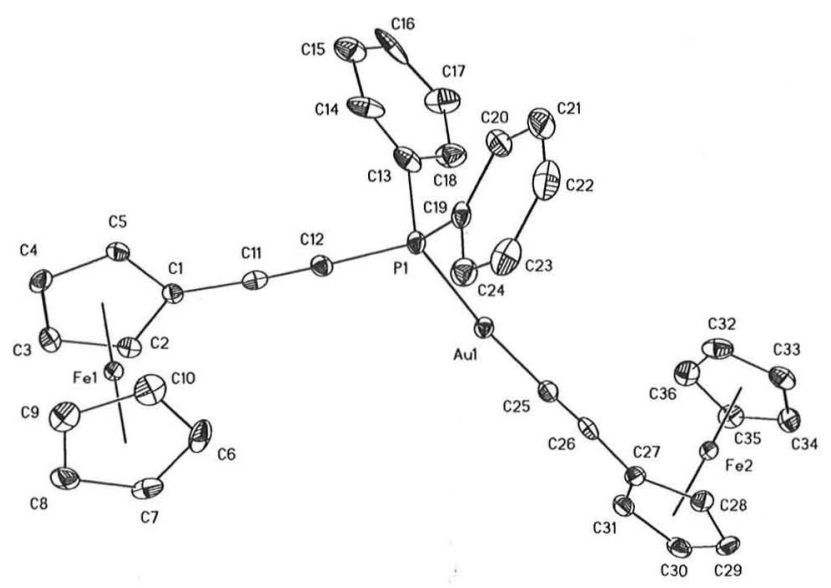

Fig. 5. ORTEP diagram (50\% probability level) of 9a with the atom-numbering scheme. (Hydrogen atoms are omitted for clarity.) 


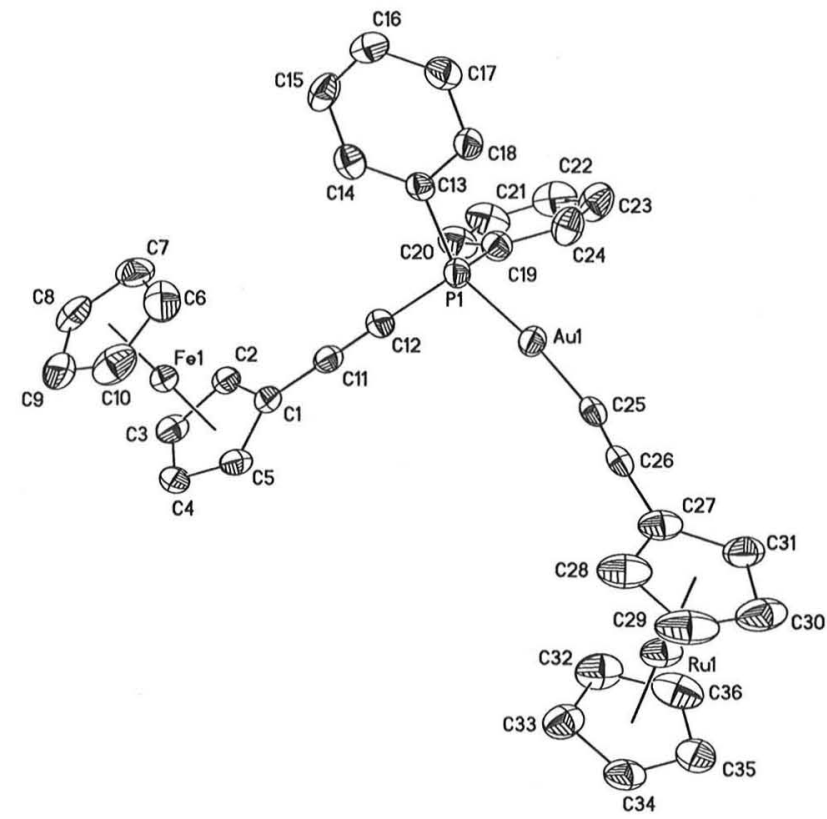

Fig. 6. ORTEP diagram (50\% probability level) of $\mathbf{9 b}$ with the atom-numbering scheme. (Hydrogen atoms and the solvent molecule dichloromethane are omitted for clarity.)

Table 3

Selected bond distances $(\AA)$ and angles $\left(^{\circ}\right)$ of complexes $8 \mathbf{a}, \mathbf{9 a}$, and $\mathbf{9 b}$.

\begin{tabular}{llll}
\hline & $\mathbf{8 a}$ & $\mathbf{9 a}$ & $\mathbf{9 b}$ \\
\hline $\begin{array}{l}\text { Bond distances } \\
\text { Au1-P1 }\end{array}$ & $\mathbf{2 . 2 1 8 8 ( 7 )}$ & $2.2779(11)$ & \\
Au-C11 & $2.2863(6)$ & & $2.2577(17)$ \\
Au1-C25 & & $2.000(5)$ & $1.9841(19)$ \\
P1-C12 & $1.739(3)$ & $1.753(4)$ & $1.741(7)$ \\
P1-C13 & $1.815(3)$ & $1.838(5)$ & $1.833(7)$ \\
P1-C19 & $1.810(3)$ & $1.821(4)$ & $1.833(7)$ \\
C11-C12 & $1.202(4)$ & $1.196(6)$ & $1.196(9)$ \\
Bond angles & & & \\
C11-C12-P1 & $168.7(2)$ & $176.8(4)$ & $177.6(6)$ \\
P1-Au1-C11 & $179.68(2)$ & & \\
P1-Au1-C25 & & $174.24(12)$ & $174.43(17)$ \\
C12-P1-C13 & $103.83(12)$ & $104.2(2)$ & $104.9(3)$ \\
C12-P1-C19 & $106.37(12)$ & $103.8(2)$ & $104.9(3)$ \\
C12-P1-Au1 & $114.35(9)$ & $118.35(15)$ & $110.0(2)$ \\
C13-P1-Au1 & $112.60(8)$ & $110.39(17)$ & $114.5(2)$ \\
C19-P1-Au1 & $114.83(9)$ & $111.32(14)$ & $116.4(2)$ \\
Au1-C25-C26 & & $175.0(4)$ & $169.6(5)$ \\
\hline
\end{tabular}

$[16,18]$. A comparison of the bond distances and bond angles in $\mathbf{9 a}$ and $\mathbf{9 b}$ shows that they are in the same range of reported assemblies featuring ferrocene-/ruthenocene-ethynyl, gold(I) alkynyl and $\mathrm{PPh}_{2}$ building blocks (vide supra) [19].

Voltammetric measurements on complexes $5,8 \mathbf{a}, 9 \mathbf{9}, \mathbf{9 b}$ and of $\left[\left(\mathrm{Ph}_{3} \mathrm{P}\right) \mathrm{AuC}=\mathrm{CFc}\right]$ were performed in $\mathrm{CH}_{2} \mathrm{Cl}_{2} /\left[{ }^{n} \mathrm{Bu}_{4} \mathrm{~N}\right] \mathrm{PF}_{6}$ as the supporting electrolyte. Relevant data with potentials referenced against the ferrocene/ferrocenium couple $[20,21]$ are collected in Table 4. Compounds $\left[\left(\mathrm{Ph}_{3} \mathrm{P}\right) \mathrm{AuC} \equiv \mathrm{CFc}\right]$ and 8a feature one, 9a and $\mathbf{9 b}$ two and $\mathbf{5}$ four redox-active metallocene-ethynyl moieties. Complex 8a and $\left[\left(\mathrm{Ph}_{3} \mathrm{P}\right) \mathrm{AuC} \equiv \mathrm{CFc}\right]$ help to establish the redox properties of the differently bonded ferrocene-ethynyl entities without possible interference from the other. Both complexes undergo a single reversible one-electron oxidation with a significantly lower oxidation potential for the gold-bonded ferrocene-
Table 4

Oxidation potentials of complexes $\left[\left(\mathrm{Ph}_{3} \mathrm{P}\right) \mathrm{AuC}=\mathrm{CFc}\right], \mathbf{5}, \mathbf{8 a}, \mathbf{9 a}$, and $\mathbf{9 b}$, $^{\mathrm{a}}$

\begin{tabular}{ll}
\hline Compound & $E_{0}$ in $V$ against the $\left[\mathrm{Fc} / \mathrm{Fc}^{+}\right]$standard \\
\hline$\left[\left(\mathrm{Ph}_{3} \mathrm{P}\right) \mathrm{AuC}=\mathrm{CFC}\right]$ & -0.005 \\
$\mathbf{5}$ & $-0.150\left(1 \mathrm{e}^{-}\right),-0.055\left(1 \mathrm{e}^{-}\right), 0.24\left(2 \mathrm{e}^{-}\right)$ \\
$\mathbf{8 a}$ & $-2.500,0.350$ \\
$\mathbf{9 a}$ & $0.000,0.260$ \\
$\mathbf{9 b}$ & $0.270^{\mathrm{b}}\left(2 \mathrm{e}^{-}\right) ; 0.255^{\mathrm{C}}$ \\
\hline${ }^{\mathrm{a}}$ Voltammograms were recorded in $\mathrm{CH}_{2} \mathrm{Cl}_{2} /\left[^{\mathrm{n}} \mathrm{Bu}_{4} \mathrm{~N}\right] \mathrm{PF}_{6}(0.1 \mathrm{M})$ the supporting \\
electrolyte.
\end{tabular}

ethynyl moiety $\left(E_{0}=-0.005 \mathrm{~V}\right.$ for $\left.\left[\left(\mathrm{Ph}_{3} \mathrm{P}\right) \mathrm{AuC} \equiv \mathrm{CFc}\right]\right)$ compared to the phosphine-bonded one $\left(E_{0}=+0.350 \mathrm{~V}\right.$ for 8a, Fig. 7).

Complex 9a combines both types of ferrocene-ethynyl subunits (metal and phosphine-bonded) within the same molecule. As a consequence, it shows two reversible one-electron waves at halfwave potentials of 0.000 and $+0.260 \mathrm{~V}$ vs. the ferrocene/ferrocenium standard (Fig. 8). With reference to $\left[\left(\mathrm{Ph}_{3} \mathrm{P}\right) \mathrm{AuC} \equiv \mathrm{CFc}\right]$ and $\left[\left((\mathrm{FCC} \equiv \mathrm{C}) \mathrm{PPh}_{2}\right) \mathrm{AuCl}\right](\mathbf{8 a})$, respectively, the first wave can be assigned to the gold-bonded ferrocene-ethynyl group and the second, more anodic one, to that of the ( $\mathrm{FCC} \equiv \mathrm{C}) \mathrm{PPh}_{2}$ ligand.

In contrast to $9 \mathrm{a}$, where a ferrocene-ethynyl unit is present, complex $9 \mathbf{b}$ features a $\sigma$-bonded ruthenocene-ethynyl ligand. Ruthenocenes are generally more difficult to oxidize than their isostructural ferrocene counterparts. Their associated radical cations are highly electrophilic and readily react with even weak nucleophiles of the supporting electrolyte solution, which often renders their oxidation irreversible $[22,23]$. Thus, an anodic shift of the gold-bonded metallocene-ethynyl based oxidation wave is expected, when compared to $9 \mathbf{a}$. In fact, complex $9 \mathbf{b}$ exhibits a partially reversible composite wave at $+0.27 \mathrm{~V}$ which is followed by a broader, smaller and irreversible peak at $E_{p}=+0.62 \mathrm{~V}(\nu=$ $0.1 \mathrm{~V} \mathrm{~s}^{-1}$. Fig. 9a-c). Voltammograms recorded at $v=20 \mathrm{mV} \mathrm{s}^{-1}$ show that the main, less anodic wave comprises two separate electron transfer events as a shoulder appears on the rising part of the forward peak of the more anodic, reversible feature. Upon increasing the sweep rate the irreversible wave shifts anodically [24] to the point, where both features merge into a single, partially reversible composite wave with reverse-to-forward peak current ratios $i_{p, \text { rev }} / i_{p f}$ in the range of $0.7-0.8$ (Fig. 9a). With increasing sweep rate the overall reversibility of the composite wave increases, while the peak current ratio between the irreversible feature near $0.6 \mathrm{~V}$ and the main peak diminishes somewhat (Fig. 9b). Cooling to $-78^{\circ} \mathrm{C}$ renders the composite wave slightly more reversible and shifts its half-wave potential to $+0.255 \mathrm{~V}$ but again without discernible resolution into separate features (Fig. 9c). This behavior can be interpreted by the reversible oxidation of the ferrocene-containing phosphine ligand and the partially reversible oxidation of the ruthenocene-ethynyl substituent, [25-27] which occur fortuitously at very similar potentials. The irreversible peak near $0.6 \mathrm{~V}$ arises from the further oxidation of the product that is formed on the chemical degradation of the oxidized ruthenocene-ethynyl moiety.

Complex 5 combines ferrocene-ethynyl substituents which are $\sigma$-bonded to a phosphorus as well as a platinum atom and hence, displays two pairs of reversible waves in the range of -0.2 to $+0.3 \mathrm{~V}$ (Fig. 10a). The first pair of waves clearly consists of two overlapping, closely-spaced one-electron events that are resolved as individual peaks in square wave voltammetry (Fig. 10 b). Halfwave potentials as determined by deconvolution are -0.150 and $-0.055 \mathrm{~V}$. With reference to $\mathbf{8 a}, \mathbf{9 a}$ and $\left[\left(\mathrm{Ph}_{3} \mathrm{P}\right) \mathrm{AuC} \equiv \mathrm{CF}\right]$ these waves can be assigned as the stepwise oxidation of the platinum-bonded ferrocene-ethynyl units. The oxidation of the 

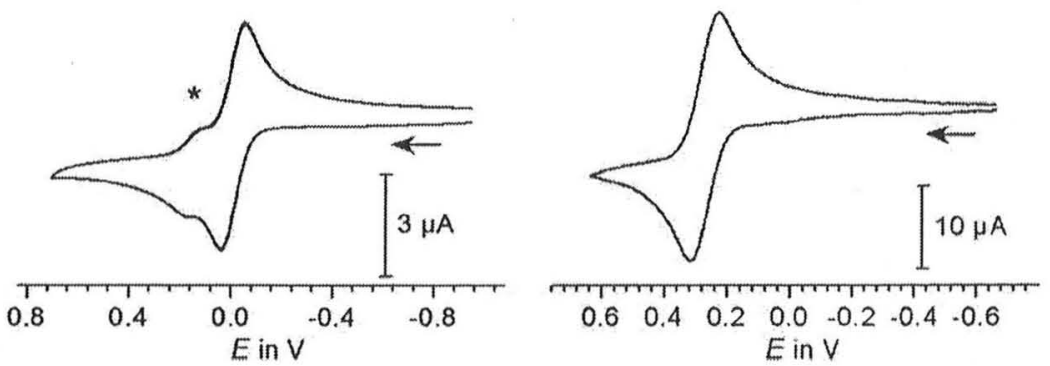

Fig. 7. Cyclic voltammograms of $\left[\left(\mathrm{PPh}_{3}\right) \mathrm{AuC} \equiv \mathrm{CFC}\right.$ (left) and $8 \mathrm{a}$ (right) $\left(10^{-3} \mathrm{M}\right.$ solution in dichloromethane at $25^{\circ} \mathrm{C}$ with [ $\left.{ }^{n} \mathrm{Bu}_{4} \mathrm{~N}\right] \mathrm{PF}$ ( $(0.1 \mathrm{M})$ as supporting electrolyte, scan rate $\left.0.10 \mathrm{~V} \mathrm{~s}^{-1}\right)$. All potentials are referenced to the $\left[\mathrm{FcH} / \mathrm{FcH}^{+}\right]$redox couple $\left(\mathrm{FcH}=\left(\eta^{5}-\mathrm{C}_{5} \mathrm{H}_{5}\right)_{2} \mathrm{Fe}\right)$ with $E_{0}=0.00 \mathrm{~V}$ [24]. The wave indicated by the symbol represents an impurity.

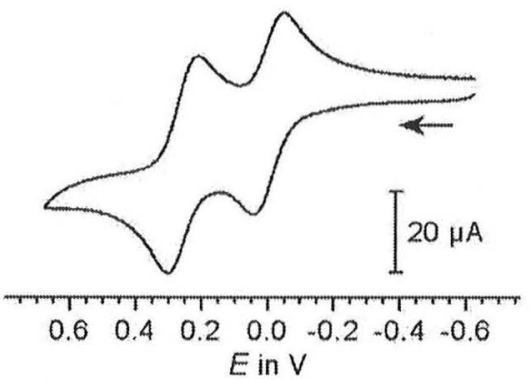

Fig. 8. Cyclic voltammogram of complex $9 \mathrm{a}\left(10^{-3} \mathrm{M}\right.$ solution in dichloromethane at $25^{\circ} \mathrm{C}$ with $\left[" \mathrm{Bu}_{4} \mathrm{~N}\right] \mathrm{PF}_{6}(0.1 \mathrm{M})$ as supporting electrolyte, scan rate $\left.0.10 \mathrm{~V} \mathrm{~s}^{-1}\right)$. All potentials are referenced to the $\left[\mathrm{FCH} / \mathrm{FCH}{ }^{+}\right]$redox couple $\left(\mathrm{FCH}=\left(\eta^{5}-\mathrm{C}_{5} \mathrm{H}_{5}\right)_{2} \mathrm{Fe}\right)$ with $E_{0}=0.00 \mathrm{~V}[24]$.

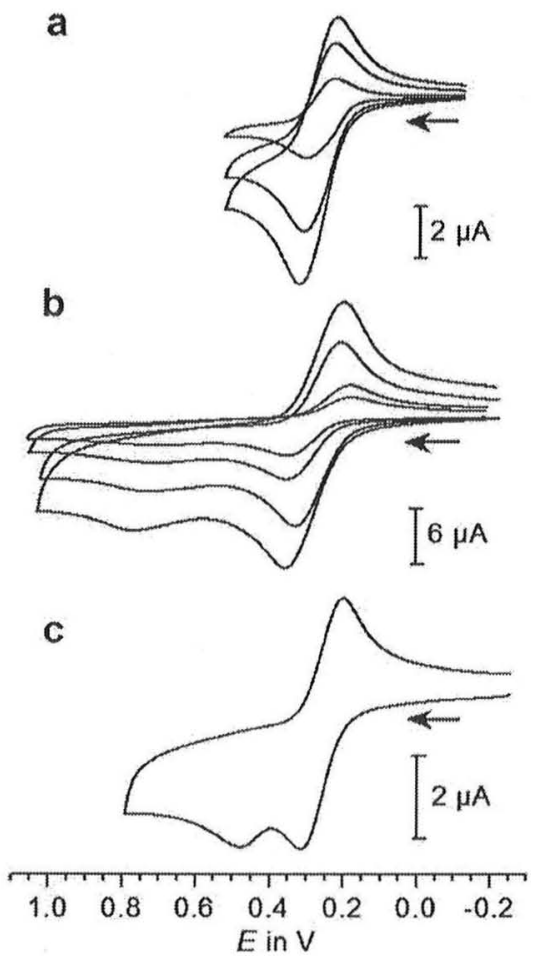

Fig. 9. Cyclic voltammograms of $\mathbf{9 b}$. (a) Scans over the first composite wave at sweep rates of $0.02,0.1$, and $0.2 \mathrm{~V} \mathrm{~s}^{-1}$ at $25^{\circ} \mathrm{C}$; (b) scans at $25^{\circ} \mathrm{C}$ over a wider potential range to include the oxidation of the follow product at $v=0.05,0.2,0.5$ and $1.0 \mathrm{~V} \mathrm{~s}^{-1}$ : (c) scan at $v=0.2 \mathrm{~V} \mathrm{~s}^{-1}$ after cooling to $-78^{\circ} \mathrm{C}\left(10^{-3} \mathrm{M}\right.$ solution in dichloromethane at $25^{\circ} \mathrm{C}$ with $\left[{ }^{n} \mathrm{Bu}_{4} \mathrm{~N}_{\mathrm{PF}}(0.1 \mathrm{M})\right.$ as supporting electrolyte). All potentials are referenced to the $\left[\mathrm{FCH} / \mathrm{FCH}^{+}\right]$redox couple $\left(\mathrm{FCH}=\left(\eta^{5}-\mathrm{C}_{5} \mathrm{H}_{5}\right)_{2} \mathrm{Fe}\right)$ with $E_{0}=0.00 \mathrm{~V}[24]$
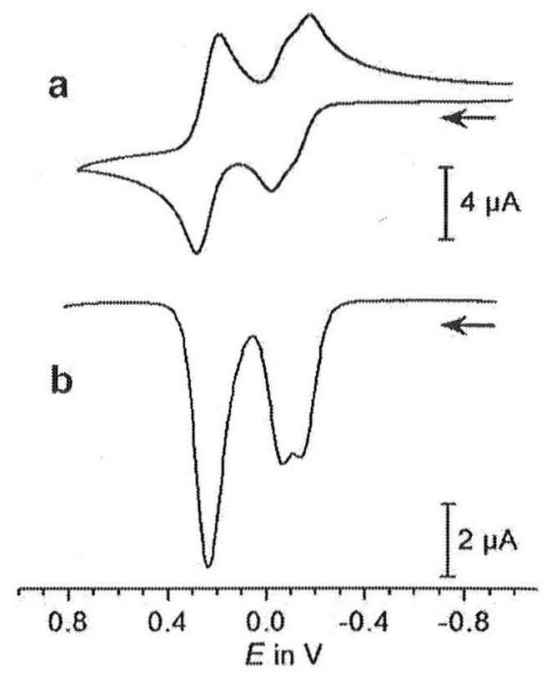

Fig. 10. (a) Cyclic voltammogram of complex 5 at $v=0.1 \mathrm{~V} \mathrm{~s}^{-1}$; (b) square wave voltammogram at $v=25 \mathrm{~Hz}$, step height $=4 \mathrm{mV}\left(10^{-3} \mathrm{M}\right.$ solution in dichloromethane at $25^{\circ} \mathrm{C}$ with $\left[{ }^{n} \mathrm{Bu}_{4} \mathrm{~N}\right] \mathrm{PF}_{6}(0.1 \mathrm{M})$ as supporting electrolyte). All potentials are referenced to the $\left[\mathrm{FcH} / \mathrm{FcH}^{+}\right]$redox couple $\left(\mathrm{FcH}=\left(\eta^{5}-\mathrm{C}_{5} \mathrm{H}_{5}\right)_{2} \mathrm{Fe}\right)$ with $E_{0}=0.00 \mathrm{~V}$ [24].

$(\mathrm{FcC} \equiv \mathrm{C}) \mathrm{PPh}_{2}$ moieties, however, occurs as a single wave or peak at $E_{0}=+0.24 \mathrm{~V}$ with the net transfer of two-electrons.

Some findings to support the idea that electronic information is conjugatively transmitted along the $\pi$-conjugated $\mathrm{MC} \equiv \mathrm{CFc}$ chain are: (i) The half-wave potentials of the ferrocene-ethynyl-based waves in $\left[\left(\mathrm{Ph}_{3} \mathrm{P}\right) \mathrm{AuC} \equiv \mathrm{CFc}\right], \mathbf{5}$ and 9a are considerably lower than in parent ethynylferrocene $(+0.16 \mathrm{~V}$ under our conditions) $[28,29]$. This reflects the electron donation by the $\sigma$-bonded $\left((\mathrm{FcC} \equiv \mathrm{C}) \mathrm{Ph}_{2} \mathrm{P}\right)_{2} \mathrm{Pt}(5),\left(\mathrm{Ph}_{3} \mathrm{P}\right) \mathrm{Au}$ or $\left((\mathrm{FcC} \equiv \mathrm{C}) \mathrm{Ph}_{2} \mathrm{P}\right) \mathrm{Au}$ (9a) units. Similar observations have been reported for a variety of other heterobimetallic ferrocene-ethynyl complexes of platinum [30], gold [31], iron [22-33], and ruthenium [31,33-36]. (ii) The oxidation potential of 5 is lower than that in $\left[\left(T p^{\text {ind }}\right) \mathrm{Ru}\left(\eta^{5}-\mathrm{C}_{5}\left(\mathrm{C}_{6} \mathrm{H}_{4}\right.\right.\right.$ $\left.\left.\left.4-\mathrm{C} \equiv \mathrm{C}-\mathrm{Pt}\left(\mathrm{PEt}_{3}\right)_{2}-\mathrm{C} \equiv \mathrm{CFC}\right)_{5}\right)\right] \quad\left(0.15 \mathrm{~V}, \mathrm{Tp}^{\mathrm{ind}}=\right.$ tris(indazolyl)borate) with a less electron donating alkynyl ligand trans to the ferrocene-ethynyl moiety [37] but close to complexes trans$\left[\mathrm{Pt}(\mathrm{C} \equiv \mathrm{CFC})\left(\mathrm{C}_{6} \mathrm{H}_{4}-4-\mathrm{X}\right)\left(\mathrm{PPh}_{3}\right)_{2}\right]\left(\mathrm{X}=\mathrm{H}, \mathrm{Me}, \mathrm{OMe}, \mathrm{Cl}, \mathrm{COMe}, \mathrm{CO}_{2} \mathrm{Me}\right)$ $[30,38]$ and trans- $\left[\left(\mathrm{Ph}_{3} \mathrm{P}\right)_{2} \mathrm{Pt}(\mathrm{C} \equiv \mathrm{CFc})_{2}\right](-0.07$ and $0.19 \mathrm{~V})$, respectively [38].

Previous work on heterobimetallic complexes of type $[\mathrm{MC} \equiv \mathrm{CMc}]^{+}(\mathrm{Mc}=\mathrm{Fc}, \mathrm{Rc})$ featuring $\sigma$-bonded metallocene-ethynyl moieties has disclosed that their singly oxidized radical cations generally display characteristic low energy absorptions in the visible or in the near infrared that are associated with the transfer of electron density from the reduced electron-rich $\mathrm{M}$ donor to the 
Table 5

Deconvoluted band maxima for $\left[\left(\mathrm{Ph}_{3} \mathrm{P}\right) \mathrm{AuC}-\mathrm{CFC}, \mathbf{5}, \mathbf{9 a}\right.$, and $\mathbf{9 b}$ in their various oxidation states.

\begin{tabular}{ll}
\hline Compound & $\lambda_{\max }$ in nm according to spectral deconvolution \\
\hline$\left[\left(\mathrm{Ph}_{3} \mathrm{P}\right) \mathrm{AuC}=\mathrm{CFC}\right]$ & $446,356,334$ \\
{$\left[\left(\mathrm{Ph}_{3} \mathrm{P}\right) \mathrm{AuC}=\mathrm{CFC}\right]$} & $855,755,560,500,410$ \\
$\mathbf{9 a}$ & $480,440,356,322$ \\
{$\left[\mathbf{9 a \mathbf { a } ^ { + }}\right.$} & $850,760,560,500,415$ \\
{$[\mathbf{9 a}]^{2+}$} & $805,700,560,460$ \\
$\mathbf{9 b}$ & $470,425,360,317$ \\
{$[\mathbf{9 b}]^{2+}$} & $700,605,475,408$ \\
$\mathbf{5}$ & $470,422,386,333$ \\
{$[\mathbf{5}]^{++}$} & $1013,444,329$ \\
{$[\mathbf{5}]^{2+}$} & $975,885,575,452,360$ \\
{$[\mathbf{5}]^{4+}$} & $951,755,572,450,360$ \\
\hline
\end{tabular}

a Similarly good fits were obtained with somewhat different parameter sets. The error in $\lambda_{\max }$ is $\pm 5 \mathrm{~nm}$ for the higher and $\pm 10 \mathrm{~nm}$ for the lower energy absorption of the oxidized forms.

oxidized $\mathrm{Mc}^{+}$acceptor site $[28,30,32,34-37,39]$. We have probed for the occurrence of similar bands in $\left[\left(\mathrm{Ph}_{3} \mathrm{P}\right) \mathrm{AuC} \equiv \mathrm{CFc}\right]$ and $9 \mathrm{a}$, $\mathbf{9 b}$, and $\mathbf{5}$ by means of in situ UV/Vis/NIR spectro-electrochemistry. The results of these investigations are summarized in Table 5. Besides the intense $n \rightarrow \pi^{*}$ and $\pi \rightarrow \pi^{*}$ type transitions of the ferrocenyl and the $\mathrm{Ph}_{3} \mathrm{P}$ moieties in the UV, compound $\left[\left(\mathrm{Ph}_{3} \mathrm{P}\right) \mathrm{AuC} \equiv \mathrm{CFC}\right]$ has a weaker, broad and asymmetric electronic absorption peaking at $446 \mathrm{~nm}$ associated with the $\mathrm{AuC} \equiv \mathrm{CF}$ moiety. Oxidation of the ferrocene-ethynyl moiety induces the growth of a new composite low energy absorption band with (deconvoluted) peak maxima of 855 and $755 \mathrm{~nm}$ and band widths of about 1550 and $2550 \mathrm{~cm}^{-1}$. Higher energy absorptions include weaker bands at 560 and $500 \mathrm{~nm}$ and a stronger absorption at $410 \mathrm{~nm}$ (Fig. 11).

The spectra of neutral $9 \mathbf{a}$ and of monooxidized [9a] ${ }^{++}$with the same oxidized $\mathrm{Fc}^{+} \mathrm{C} \equiv \mathrm{CAu}$ unit as in $\left[\left(\mathrm{Ph}_{3} \mathrm{P}\right) \mathrm{AuC} \equiv \mathrm{CFc}\right]^{+}$closely resemble the ones observed for the simpler $\mathrm{PPh}_{3}$ ligated compound in its respective oxidation state (Table 5, Fig. 12a) with a composite low-energy band with deconvoluted peak maxima of 850 and $760 \mathrm{~nm}$, weaker bands at 560 and $500 \mathrm{~nm}$ and a stronger absorption at $415 \mathrm{~nm}$. Upon the second, $(\mathrm{FcC} \equiv \mathrm{C}) \mathrm{Ph}_{2} \mathrm{P}$-based oxidation to $[\mathbf{9 a}]^{2+}$ the low energy bands intensify and experience a blue shift of about 700 and $900 \mathrm{~cm}^{-1}$ to 805 and $700 \mathrm{~nm}$ (Fig. 12b). This blue shift probably reflects the lowering of the $\left((\mathrm{FcC} \equiv \mathrm{C}) \mathrm{Ph}_{2} \mathrm{P}\right) \mathrm{Au}$-based donor orbitals as a consequence of the oxidation of the $(\mathrm{FcC}=\mathrm{C}) \mathrm{Ph}_{2} \mathrm{P}$ ligand. The latter event is expected to increase the energy of the $\left(\mathrm{RPh}_{2} \mathrm{P}\right) \mathrm{Au} \rightarrow \mathrm{C} \equiv \mathrm{CFc}^{+}$charge-transfer $(\mathrm{CT})$ transition.

The ruthenocene analog $\mathbf{9 b}$, despite its only partially reversible behavior in cyclic voltammetry, gave still useful results under the

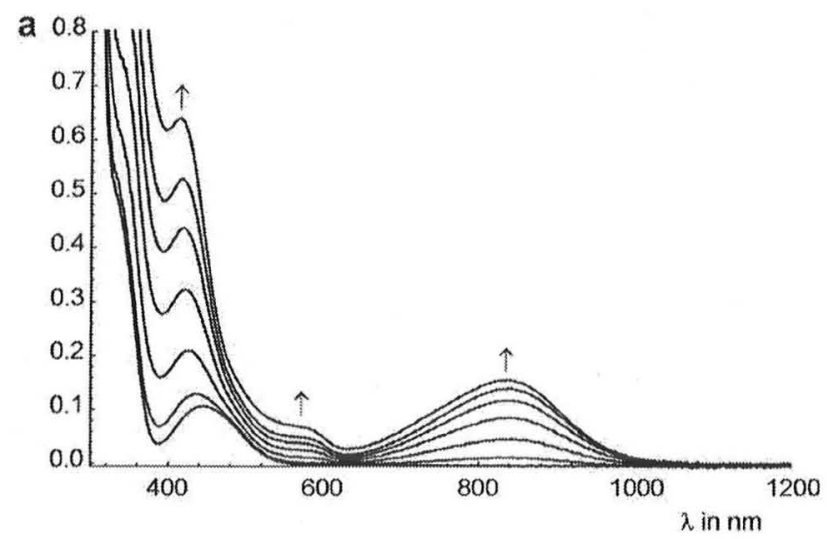

Fig. 11. Spectroscopic changes upon oxidation of $\left[\left(\mathrm{Ph}_{3} \mathrm{P}\right) \mathrm{AuC} \equiv \mathrm{CFc}\right]\left(1,2-\mathrm{C}_{2} \mathrm{H}_{4} \mathrm{Cl}_{2}\right]$ $\left.\left[{ }^{n} \mathrm{Bu}_{4} \mathrm{~N}\right] \mathrm{PF}_{6}\right)$ in an OTTLE cell.
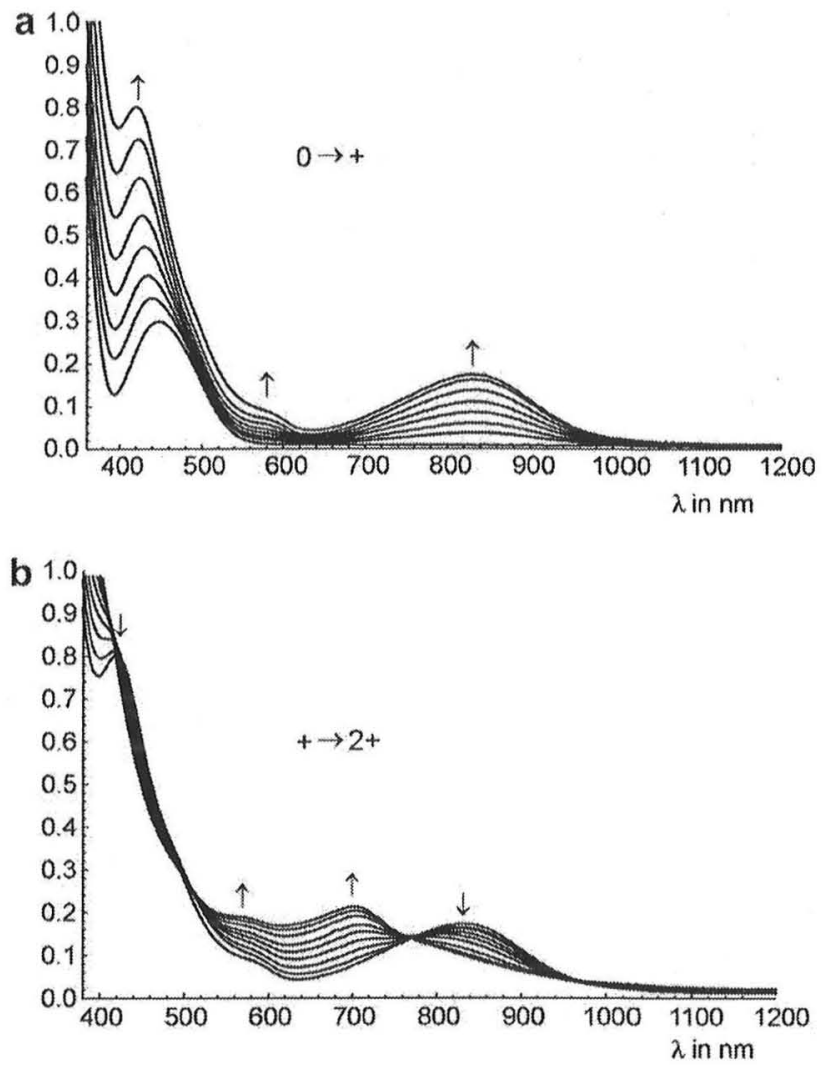

Fig. 12. Spectroscopic changes upon stepwise oxidation of 9a $\left(1,2-\mathrm{C}_{2} \mathrm{H}_{4} \mathrm{Cl}_{2}\right.$ $\left[{ }^{n} \mathrm{Bu}_{4} \mathrm{~N}\right] \mathrm{PF}_{6}$ ) in an OTTLE cell. (a) Spectroscopic changes upon the first oxidation to $[\mathbf{9 a}]^{+}$, (b) the second oxidation to $[\mathbf{9 a}]^{2+}$.

thin-layer conditions of in situ spectro-electrochemistry. Spectra obtained after a full oxidation/reduction cycle were very similar to those of pristine $\mathbf{9 b}$. Characteristic bands of oxidized $\mathbf{9 b}$ (which is probably present as $[\mathbf{9 b}]^{2+}$ ) appear at 700 and $605 \mathrm{~nm}$, and thus at higher energies as in the ferrocene-ethynyl counterpart $[\mathbf{9 a}]^{2+}$. These differences may relate to the well-known propensity of oxidized ruthenocene-ethynyls to rearrange to cyclopentadienylidene type structures [25-27].

The resolved, stepwise oxidations of the platinum-bonded $\mathrm{C} \equiv \mathrm{CF}$ moieties of complex 5 raise the question whether they are electronically coupled across the platinum center or not. While $\left(R_{3} P\right)_{2} \mathrm{Pt}$ entities are usually regarded as insulating [30,40,41], some accounts of $\pi$-delocalization along the $\mathrm{RC} \equiv \mathrm{C}-\mathrm{Pt}-\mathrm{C} \equiv \mathrm{CR}$ axis in trans-dialkynyl platinum complexes have already appeared [38,39,42-44].

Such an "electronic coupling" should give rise to a low-energy absorption band at the mixed-valent [5].+ state but not in the bordering 5 and $[\mathbf{5}]^{2+}$ states, where both $\mathrm{C} \equiv \mathrm{CFc}$ moieties are present in either their reduced or oxidized states. The analysis of the electronic spectra of $[5]^{+*}$ is, however, complicated by the proximity of the two PtC $\equiv$ CFc-based oxidation waves. The $0.095 \mathrm{~V}$ splitting of half-wave potentials translates via Eq. (1) into a comproportionation constant of 40 for the intermediate mono-cation. In Eq. (3), $n$ denotes the number of transferred electrons, $F$ is Faraday's constant, and $R$ and $T$ have their usual meaning.

$[5]^{2+}+[5] \rightleftarrows 2[5]^{+} ; K_{\text {comp }}=\exp \left[n \cdot F \cdot \Delta E_{0} /(R \cdot T)\right]$

In such a constellation, spectra recorded at any stage during the first two oxidations represent mixtures of neutral $\mathbf{5}$, monoxidized $[5]^{++}$and $[5]^{2+}$ (Fig. 13a and b). From the spectra of neutral 5 and 

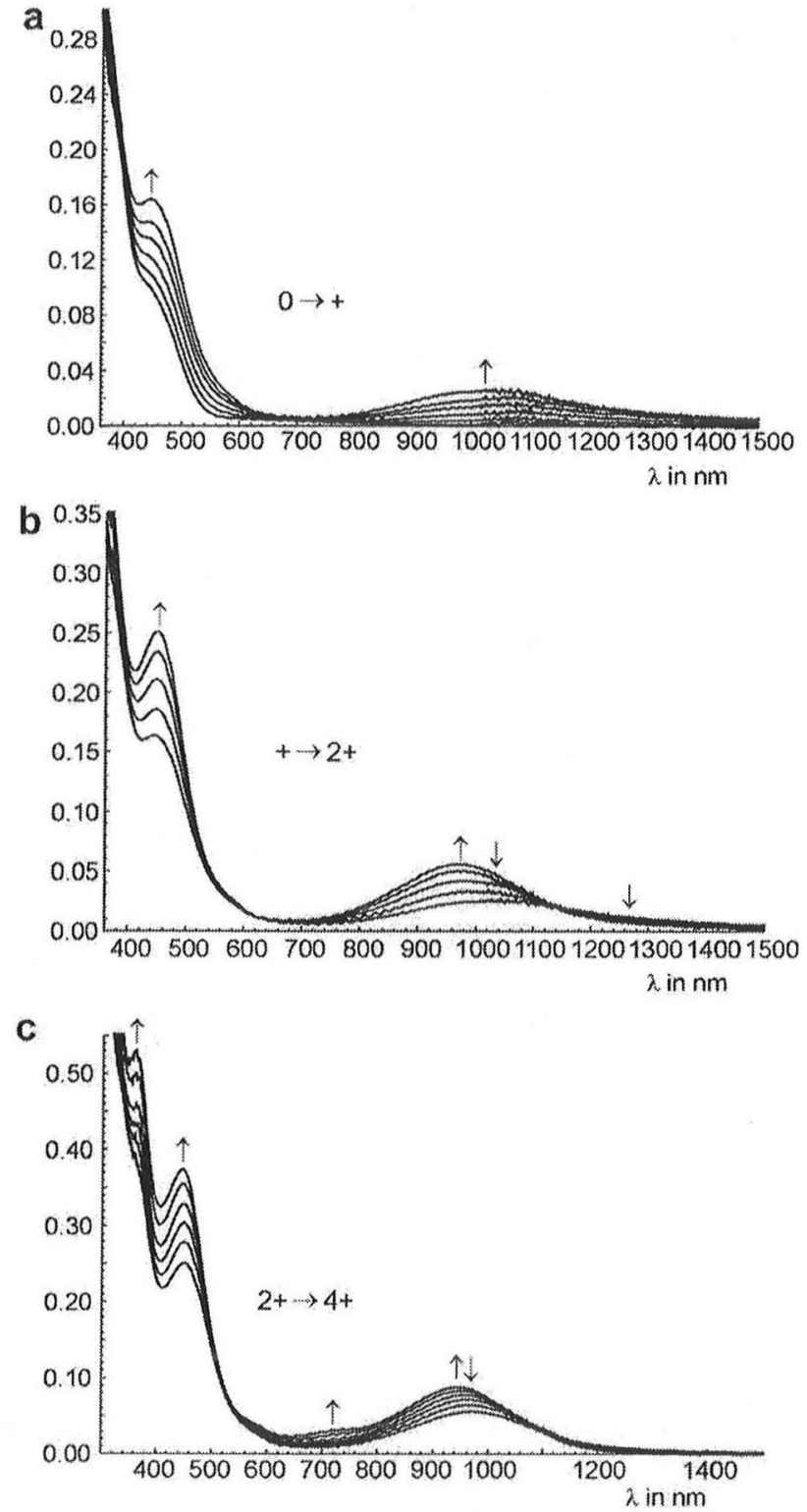

Fig. 13. Spectroscopic changes upon stepwise oxidation of $5\left(1,2-\mathrm{C}_{2} \mathrm{H}_{4} \mathrm{Cl}_{2} /\right.$ $\left[{ }^{n} \mathrm{Bu}_{4} \mathrm{~N}\right] \mathrm{PF}_{6}$ ) in an OTTLE cell. (a) Spectroscopic changes upon the first oxidation to $[5]^{*}$. (b) the second oxidation to $[5]^{2+}$ and (c) the third oxidation to $[5]^{4+}$

dioxidized $[5]^{2+}$ and from the value of the comproportionation constant $K_{\text {comp }}$ the spectrum of $[5]^{+}$can be calculated. It is given as Fig. 14. The low energy portion of the spectrum is adequately simulated by a single band peaking at $1013 \mathrm{~nm}$. Given the general appearance of low energy absorptions in every complex with a metal-bonded oxidized $\mathrm{C} \equiv \mathrm{CFc}^{+}$moiety, we assign this band to the $\mathrm{Pt} \rightarrow \mathrm{C} \equiv \mathrm{CFc}^{+}$charge transfer transition. The absence of any discernible $\mathrm{FcC} \equiv \mathrm{C} \rightarrow \mathrm{FcC} \equiv \mathrm{C}^{+}$intervalence charge transfer band characterizes $[\mathbf{5}]^{+}$as a localized mixed-valent system [45].

In analogy to complex 9a and in further keeping with the $\mathrm{Pt} \rightarrow \mathrm{C} \equiv \mathrm{CFc}^{+}$assignment, the $1013 \mathrm{~nm}$ band of $[5]^{+}$undergoes a stepwise blue shift with a concomitant increase in overall intensity as further ferrocene tags are oxidized $\left([5]^{+} \rightarrow[5]^{2+},[5]^{2+} \rightarrow[5]^{4+}\right.$, Fig. $13 \mathrm{~b}$ and c). For both, $[5]^{2+}$ and $[5]^{4+}$, the band envelope is notably asymmetric and requires the inclusion of two separate absorptions in the deconvolution procedure (see Table 5).

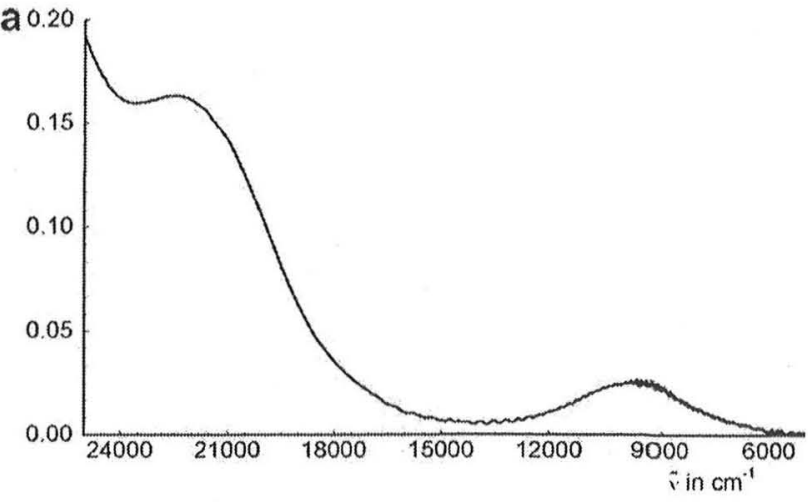

Fig. 14. Calculated spectrum of singly oxidized $[5]^{-+}$

According to Eq. (4), the band maximum of a charge transfer band in a heterobimetallic, (formally) mixed-valent system depends on the redox asymmetry between the dislike redox sites. This is expressed by the energy difference $\Delta G^{\circ}$ between the different valence tautomers ( $\mathrm{MC} \equiv \mathrm{CFc}^{+}$and $\mathrm{M}^{+} \mathrm{C} \equiv \mathrm{CFc}$ ), while $\lambda$ represents the reorganization energy. Further examples within the context of $\mathrm{MC} \equiv \mathrm{CMc}^{+}$systems have been reported by Sato et al. $[30,32,36,39]$.

$\tilde{v}_{\max }=\lambda+\Delta G^{\circ}$

The blue shift of the relevant low-energy absorption band upon replacement of $\operatorname{Pt}\left(\mathrm{PPh}_{3}\right)_{2}\left(\mathrm{C} \equiv \mathrm{CFc}^{n+}\right)\left(n=0,5 ; n=1:[5]^{+}\right)$by $\mathrm{Au}\left(\mathrm{PR}_{2} \mathrm{R}^{\prime}\right)$ moieties $\left(\mathrm{R}^{\prime}=\mathrm{Ph}\right.$ or $\mathrm{C} \equiv \mathrm{CFC}^{n+}\left(n=0,[\mathbf{9 a}]^{+} ; n=1:[\mathbf{9 a}]^{2+}\right)$ and upon the oxidation of ferrocene-ethynyl substituents at the phosphine co-ligand is understandable on that basis. Also pertinent to the systems in the current study are complexes trans-[FcC $\left.\equiv \mathrm{CPt}\left(\mathrm{PPh}_{3}\right)_{2}\left(\mathrm{C}_{6} \mathrm{H}_{4}-4-\mathrm{X}\right)\right]$, where the $\mathrm{PtC} \equiv \mathrm{CFc}^{+}$band systematically blue shifts as the $\sigma_{p}^{+}$parameter of the para-substituent $X$ increases. [30] Our value of $9870 \mathrm{~cm}^{-1}(1013 \mathrm{~nm})$ for $[5]^{+}$ slightly exceeds those observed for the above aryl complexes $\left(9300-9480 \mathrm{~cm}^{-1}\right)$. The $\left.\left[(\mathrm{FCC} \equiv \mathrm{C}) \mathrm{Ph}_{2} \mathrm{P}\right)_{2} \mathrm{Pt}(\mathrm{C} \equiv \mathrm{CFc})\right]$ entity thus appears to be slightly less electron donating than $\left[\mathrm{Pt}\left(\mathrm{PPh}_{3}\right)_{2}\left(\mathrm{C}_{6} \mathrm{H}_{4}\right.\right.$ $(-4-\mathrm{COMe}))]$, while the $\left(\mathrm{Ph}_{3} \mathrm{P}\right) \mathrm{Au}$ and $\left((\mathrm{FcC} \equiv \mathrm{C}) \mathrm{Ph}_{2} \mathrm{P}\right) \mathrm{Au}$ entities are even weaker donors. This also matches the trends in the oxidation potentials of the metal bonded $\mathrm{FcC} \equiv \mathrm{C}$ subunit (Table 4 ).

\section{Conclusion}

Different synthesis methods for the preparation of ferroceneethynyl phosphine and phosphine oxide transition metal complexes of structural type $(\mathrm{FCC} \equiv \mathrm{C})_{3} \mathrm{P}=\mathrm{O},\left[\left((\mathrm{FCC} \equiv \mathrm{C})_{n} \mathrm{Ph}_{3-n} \mathrm{P}\right) \mathrm{AuCl}\right](n=1,2)$, $\left[\left((\mathrm{FcC} \equiv \mathrm{C}) \mathrm{Ph}_{2} \mathrm{P}\right) \mathrm{AuC} \equiv \mathrm{CMc}\right],\left[\left((\mathrm{FCC} \equiv \mathrm{C})_{n} \mathrm{Ph}_{3-n} \mathrm{P}\right) \mathrm{AuC} \equiv \mathrm{CMc}\right](n=1$, 2), cis-[((FcC $\left.\left.\equiv \mathrm{C})_{n} \mathrm{Ph}_{3-n} \mathrm{P}\right)_{2} \mathrm{PtCl}_{2}\right]$ and trans-[(( $\left.\left.\mathrm{FCC} \equiv \mathrm{C}\right) \mathrm{Ph}_{2} \mathrm{P}\right)_{2} \mathrm{Pt}(\mathrm{C} \equiv$ $\left.\mathrm{CFc})_{2}\right] \quad\left(\mathrm{Mc}=\mathrm{Fc}, \quad \mathrm{Rc} ; \quad \mathrm{Fc}=\left(\eta^{5}-\mathrm{C}_{5} \mathrm{H}_{5}\right)\left(\eta^{5}-\mathrm{C}_{5} \mathrm{H}_{4}\right) \mathrm{Fe} ; \quad \mathrm{Rc}=\left(\eta^{5}-\mathrm{C}_{5} \mathrm{H}_{5}\right)\right.$ $\left.\left(\eta^{5}-\mathrm{C}_{5} \mathrm{H}_{4}\right) \mathrm{Ru}\right)$ are reported. In these species ferrocene and/or ruthenocene sandwich units are interconnected by ethynyl phosphine and metal-ethynyl bridging units. Electrochemical studies show chemically reversible oxidations of the metal and phosphinebonded FCC $\equiv \mathrm{C}$ moieties. The half-wave potentials of these processes respond to the electron density at the heterometal moiety. Upon oxidation of the $\sigma$-bonded $\mathrm{McC} \equiv \mathrm{C}$ entities low energy absorption bands appear in the near infrared that are likely associated with the transfer of charge from the heterometal atom $M$ to $\mathrm{C} \equiv \mathrm{CMc}^{+}$. These bands show the expected blue shift as $\mathrm{M}$ becomes less electron donating, i.e., as the redox asymmetry between the $\mathrm{M}$ and $\mathrm{FCC} \equiv \mathrm{C}$ redox sites increases. Our results also argue against any "electronic coupling" between the oxidized $\mathrm{Fc}^{+}$and the reduced Fc site across the $-\mathrm{C} \equiv \mathrm{C}-\mathrm{Pt}\left(\mathrm{PPh}_{2}(\mathrm{C} \equiv \mathrm{CFc})\right)_{2}-\mathrm{C} \equiv \mathrm{C}$ - linker in monooxidized $[\mathbf{5}]^{+}$despite the $95 \mathrm{mV}$ splitting of redox potentials. 


\section{Experimental}

\subsection{General data}

All reactions were carried out under an atmosphere of nitrogen using standard Schlenk techniques. Tetrahydrofuran, diethyl ether, $n$-hexane and $n$-pentane were purified by distillation from sodium/ benzophenone ketyl; dichloromethane was purified by distillation from calcium hydride. Celite (purified and annealed, Erg. B.6, Riedel de Haen) was used for filtrations.

\subsection{Instruments}

Infrared spectra were recorded with a Perkin-Elmer FT-IR spectrometer Spectrum 1000. ${ }^{1} \mathrm{H}$ NMR spectra were recorded with a Bruker Avance 250 spectrometer operating at $250.130 \mathrm{MHz}$ in the Fourier transform mode; ${ }^{13} \mathrm{C}\left\{{ }^{1} \mathrm{H}\right\}$ NMR spectra were recorded at $62.860 \mathrm{MHz}$. Chemical shifts are reported in $\delta$ units (parts per million) downfield from tetramethylsilane with the solvent as reference signal ( ${ }^{1} \mathrm{H}$ NMR: $\mathrm{CDCl}_{3}(99.8 \%), \delta=7.26 ;\left(\mathrm{CD}_{3}\right)_{2} \mathrm{CO}(99.9 \%)$, $\delta=2.05 ; \mathrm{CD}_{3} \mathrm{CN}$ (99.8\%), $\delta=1.94 .{ }^{13} \mathrm{C}\left\{{ }^{1} \mathrm{H}\right\}$ NMR: $\mathrm{CDCl}_{3}$ (99.8\%), $\left.\delta=77.16 ;\left(\mathrm{CD}_{3}\right)_{2} \mathrm{CO}(99.9 \%), \delta=29.84,206.26\right)$. The abbreviation pt in the ${ }^{1}$ H NMR spectra corresponds to pseudo-triplet. Cyclic voltammograms were recorded in a dried cell purged with purified argon. Platinum wires served as working electrode and counter electrode. A saturated calomel electrode in a separated compartment or a silver wire served as (pseudo)reference electrode. In the latter case, potential calibration was done by addition of ferrocene to the analyte solution. All electrode potentials are converted using the redox potential of the ferrocene-ferrocenium couple $\left[\mathrm{FcH} / \mathrm{FcH}{ }^{+}\right]\left(\mathrm{FcH}=\left(\eta^{5}-\mathrm{C}_{5} \mathrm{H}_{5}\right)_{2} \mathrm{Fe}, E_{0}=0.00 \mathrm{~V},[20,21]\right.$ as reference. Electrolyte solutions were prepared from tetrahydrofuran (for 5) or dichloromethane (for 9a and 9b) and $\left[{ }^{n} \mathrm{Bu}_{4} \mathrm{~N} \mathrm{PF}_{6}\right.$ (Fluka, dried in oil-pump vacuum). The respective organometallic complexes were added at $c=1.0 \mathrm{mM}$. Cyclic voltammograms were recorded using a Voltalab 3.1 potentiostat (Radiometer) equipped with a digital electrochemical analyzer DEA 101 and an electrochemical interface IMT 102 or a BAS CV 50 instrument. Spectro-electrochemistry was performed in a home-built optically transparent thinlayer electrolysis (OTTLE) cell following the design of Hartl and coworkers [46]. Melting points were determined using analytically pure samples, sealed off in nitrogen purged capillaries on a Gallenkamp MFB $595010 \mathrm{M}$ melting point apparatus. Microanalyses were performed by the Institute of Organic Chemistry, Chemnitz, University of Technology and by the Institute of Organic Chemistry, University of Heidelberg.

\subsection{Reagents}

$\mathrm{FcC} \equiv \mathrm{CH} \quad[47 \mathrm{a}], \quad \mathrm{RcC} \equiv \mathrm{CH} \quad[47 \mathrm{~b}], \quad\left[(\mathrm{PhC} \equiv \mathrm{N})_{2} \mathrm{PtCl}_{2}\right] \quad[48]$, [(tht)AuCl] [49], and $(\mathrm{FCC} \equiv \mathrm{C})_{n} \mathrm{Ph}_{3-n} \mathrm{P}(n=1,2,3)[5 \mathrm{~b}]$ were prepared according to published procedures. All other chemicals were purchased by commercial suppliers and were used without further purification.

\subsection{Synthesis of cis-[(FCC $\left.\left.\equiv \mathrm{C}) \mathrm{Ph}_{2} \mathrm{P}\right)_{2} \mathrm{PtCl}_{2}\right](3 \boldsymbol{a})$}

One hundred milligrams $(0.21 \mathrm{mmol})$ of $\left[(\mathrm{PhC} \equiv \mathrm{N})_{2} \mathrm{PtCl}_{2}\right](2)$ and $167 \mathrm{mg}(0.42 \mathrm{mmol})$ of $(\mathrm{FcC} \equiv \mathrm{C}) \mathrm{Ph}_{2} \mathrm{P}(\mathbf{1 a})$ were dissolved in $40 \mathrm{~mL}$ of dichloromethane and were stirred for $1 \mathrm{~h}$ at $25^{\circ} \mathrm{C}$. Afterward the reaction solution was reduced in volume under reduced pressure and the orange title compound was precipitated by addition of petroleum ether. Yield: $190 \mathrm{mg}(0.18 \mathrm{mmol}, 85 \%$ based 2$)$

Anal. Calc. for $\mathrm{C}_{48} \mathrm{H}_{38} \mathrm{Cl}_{2} \mathrm{Fe}_{2} \mathrm{P}_{2} \mathrm{Pt}$ (1053.02): C, 54.70; $\mathrm{H}, 3.64$. Found: C, 54.23; H, 3.65\%. M.p.: $216{ }^{\circ} \mathrm{C}$ (decomp.). IR $\left(\mathrm{KBr}, \mathrm{cm}^{-1}\right)$ : $2159\left(\mathrm{~s}, v_{\mathrm{C} \equiv \mathrm{c})} .{ }^{1} \mathrm{H}\right.$ NMR $\left(\delta, \mathrm{CDCl}_{3}\right): 4.04\left(\mathrm{~s}, 10 \mathrm{H}, \mathrm{C}_{5} \mathrm{H}_{5}\right), 4.16(\mathrm{pt}$,
$\left.J_{\mathrm{HH}}=1.9 \mathrm{~Hz}, H^{\prime} / \mathrm{C}_{5} \mathrm{H}_{4}\right), 4.21\left(\mathrm{pt}, J_{\mathrm{HH}}=1.7 \mathrm{~Hz}, H^{\alpha} / \mathrm{C}_{5} \mathrm{H}_{4}\right), 7.35-7.53$ $\left(\mathrm{m}, 12 \mathrm{H}, \mathrm{C}_{6} \mathrm{H}_{5}\right), 7.81-7.97\left(\mathrm{~m}, 8 \mathrm{H}, \mathrm{C}_{6} \mathrm{H}_{5}\right) \cdot{ }^{13} \mathrm{C}\left\{{ }^{1} \mathrm{H}\right\} \operatorname{NMR}\left(\delta, \mathrm{CDCl}_{3}\right)$ $61.3\left(C^{i} / \mathrm{C}_{5} \mathrm{H}_{4}\right), 70.0\left(C^{\beta} / \mathrm{C}_{5} \mathrm{H}_{4}\right), 70.2\left(\mathrm{C}_{5} \mathrm{H}_{5}\right), 72.8\left(\mathrm{C}^{\alpha} / \mathrm{C}_{5} \mathrm{H}_{4}\right), 111.0$ $(\mathrm{C} / \mathrm{C} \equiv \mathrm{C}), 128.3\left(\mathrm{~d}, J_{\mathrm{CP}}=6.4 \mathrm{~Hz} \mathrm{C}^{m} / \mathrm{C}_{6} \mathrm{H}_{5}\right), 129.3\left(\mathrm{~d}, J_{\mathrm{CP}}=77.4 \mathrm{~Hz}\right.$ $\left.C^{i} / \mathrm{C}_{6} \mathrm{H}_{5}\right), 131.3\left(\mathrm{C}^{p} / \mathrm{C}_{6} \mathrm{H}_{5}\right), 133.8\left(\mathrm{pt}, J_{\mathrm{CP}}=6.1 \mathrm{~Hz}, \mathrm{C}^{\circ} / \mathrm{C}_{6} \mathrm{H}_{5}\right) .{ }^{31} \mathrm{P}\left\{{ }^{1} \mathrm{H}\right\}$ $\operatorname{NMR}\left(\delta, \mathrm{CDCl}_{3}\right):-12.1\left(J_{31_{\mathrm{p}} 195 \mathrm{pt}_{\mathrm{t}}}=3760 \mathrm{~Hz}\right)$.

\subsection{Synthesis of cis- $\left[\left((\mathrm{FCC} \equiv C)_{2} \mathrm{PhP}\right)_{2} \mathrm{PtCl} \mathrm{Cl}_{2}\right](\mathbf{3} \boldsymbol{b})$}

Complex 3b was synthesized on a similar manner as discussed for 3a: $70 \mathrm{mg}(0.15 \mathrm{mmol})$ of $\left[(\mathrm{PhC} \equiv \mathrm{N})_{2} \mathrm{PtCl}_{2}\right](2), 156 \mathrm{mg}$ $(0.30 \mathrm{mmol})$ of $(\mathrm{FcC} \equiv \mathrm{C})_{2} \mathrm{PhP}(\mathbf{1 b})$. After appropriate work-up, complex $\mathbf{3 b}$ was obtained as an orange solid. Yield: $180 \mathrm{mg}(0.14 \mathrm{mmol}$, $92 \%$ based on 2 ).

Anal. Calc. for $\mathrm{C}_{60} \mathrm{H}_{48} \mathrm{Cl}_{2} \mathrm{Fe}_{4} \mathrm{P}_{2} \mathrm{Pt}$ (1318.97): C, 54.59; $\mathrm{H}, 3.67$. Found: C, 54.23; $\mathrm{H}, 3.65 \%$. M.p.: $146{ }^{\circ} \mathrm{C}$ (decomp.). IR ( $\mathrm{KBr}, \mathrm{cm}^{-1}$ ): $2158\left(\mathrm{~s}, v_{\mathrm{C}} \equiv \mathrm{c}\right) .{ }^{1} \mathrm{H}$ NMR $\left(\delta, \mathrm{CDCl}_{3}\right): 4.20\left(\mathrm{~s}, 20 \mathrm{H}, \mathrm{C}_{5} \mathrm{H}_{5}\right), 4.25(\mathrm{pt}$, $\left.J_{\mathrm{HH}}=1.9 \mathrm{~Hz}, 8 \mathrm{H}, H^{\beta} / \mathrm{C}_{5} \mathrm{H}_{4}\right), 4.41\left(\mathrm{pdq}, J_{\mathrm{HH}}=11.6 \mathrm{~Hz}, J_{\mathrm{HH}}=1.4 \mathrm{~Hz}\right.$, $\left.J_{\mathrm{HH}}=1.9 \mathrm{~Hz}, 8 \mathrm{H}, H^{\alpha} / \mathrm{C}_{5} \mathrm{H}_{4}\right), 7.45-7.59\left(\mathrm{~m}, 6 \mathrm{H}, \mathrm{C}_{6} \mathrm{H}_{5}\right), 8.18-8.32(\mathrm{~m}$, $\left.4 \mathrm{H}, \mathrm{C}_{6} \mathrm{H}_{5}\right) \cdot{ }^{13} \mathrm{C}\left\{{ }^{1} \mathrm{H}\right\}$ NMR $\left(\delta, \mathrm{CDCl}_{3}\right): 61.4\left(\mathrm{C}^{\mathrm{i}} / \mathrm{C}_{5} \mathrm{H}_{4}\right), 70.1\left(\mathrm{C}^{\beta} / \mathrm{C}_{5} \mathrm{H}_{4}\right)$ $70.5\left(\mathrm{C}_{5} \mathrm{H}_{5}\right), 72.5\left(C^{\alpha} / \mathrm{C}_{5} \mathrm{H}_{4}\right), 128.7\left(\mathrm{~d}, J_{\mathrm{CP}}=7.1 \mathrm{~Hz}, \mathrm{C}^{m} / \mathrm{C}_{6} \mathrm{H}_{5}\right), 128.9$ $\left(C^{i} / \mathrm{C}_{6} \mathrm{H}_{5}\right), 131.8\left(C^{p} / \mathrm{C}_{6} \mathrm{H}_{5}\right), 133.4\left(\mathrm{pt}, J_{\mathrm{CP}}=7.4 \mathrm{~Hz}, \mathrm{C}^{\circ} / \mathrm{C}_{6} \mathrm{H}_{5}\right) .{ }^{31} \mathrm{P}\left\{{ }^{1} \mathrm{H}\right\}$ $\operatorname{NMR}\left(\delta, \mathrm{CDCl}_{3}\right):-43.2\left(\mathrm{~J}_{31 \mathrm{p} 195 \mathrm{pt}}=3886 \mathrm{~Hz}\right)$.

\subsection{Synthesis of cis- $\left.I\left((\mathrm{FCC} \equiv \mathrm{C})_{3} \mathrm{P}\right)_{2} \mathrm{PtCl}_{2}\right](3 \mathrm{c})$}

Complex $\mathbf{3 c}$ was synthesized in a similar manner as described for 3a: $165 \mathrm{mg}(0.35 \mathrm{mmol})$ of $\left[(\mathrm{PhC} \equiv \mathrm{N})_{2} \mathrm{PtCl}_{2}\right]$ (2), $460 \mathrm{mg}$ $(0.70 \mathrm{mmol})$ of $(\mathrm{FcC} \equiv \mathrm{C})_{3} \mathrm{P}(1 \mathrm{c})$. After appropriate work-up, complex 3c was isolated as an orange solid. Yield: $515 \mathrm{mg}(0.33 \mathrm{mmol}$, 93\% based on 2 ).

Anal. Calc. for $\mathrm{C}_{72} \mathrm{H}_{54} \mathrm{Cl}_{2} \mathrm{Fe}_{6} \mathrm{P}_{2} \mathrm{Pt}$ (1580.88): C, 54.65; $\mathrm{H}, 3.44$. Found: $\mathrm{C}, 54.41 ; \mathrm{H}, 3.34 \%$. M.p.: $135^{\circ} \mathrm{C}$ (decomp.). IR $\left(\mathrm{KBr}, \mathrm{cm}^{-1}\right)$ : $2156\left(\mathrm{~s}, v_{\mathrm{C} \equiv \mathrm{C}}\right) .{ }^{1} \mathrm{H}$ NMR $\left(\delta, \mathrm{CDCl}_{3}\right): 4.29\left(\mathrm{pt}, J_{\mathrm{HH}}=1.9 \mathrm{~Hz}, 12 \mathrm{H}, H^{\beta}\right.$ $\left.\mathrm{C}_{5} \mathrm{H}_{4}\right), 4.30\left(\mathrm{~s}, 30 \mathrm{H}, \mathrm{C}_{5} \mathrm{H}_{5}\right), 4.61\left(\mathrm{pt}, J_{\mathrm{HH}}=1.9 \mathrm{~Hz}, 12 \mathrm{H}, H^{\alpha} / \mathrm{C}_{5} \mathrm{H}_{4}\right)$. ${ }^{13} \mathrm{C}\left\{{ }^{1} \mathrm{H}\right\}$ NMR $\left(\delta, \mathrm{CDCl}_{3}\right): 61.2\left(\mathrm{C}^{\mathrm{i}} / \mathrm{C}_{5} \mathrm{H}_{4}\right), 70.3\left(C^{\beta} / \mathrm{C}_{5} \mathrm{H}_{4}\right), 70.8\left(C^{\alpha} /\right.$ $\left.\mathrm{C}_{5} \mathrm{H}_{4}\right), \quad 72.7 \quad\left(\mathrm{C}_{5} \mathrm{H}_{5}\right) . \quad{ }^{31} \mathrm{P}\left\{{ }^{1} \mathrm{H}\right\} \quad \mathrm{NMR} \quad\left(\delta, \quad \mathrm{CDCl}_{3}\right): \quad-77.1$ $\left(J_{31 \mathrm{p} 195 \mathrm{pt}_{\mathrm{t}}}=4029 \mathrm{~Hz}\right)$.

\subsection{Synthesis of trans- $\left.I\left((F C C \equiv C) P h_{2} P\right)_{2} P t(C \equiv C F C)_{2}\right](5)$}

To $170 \mathrm{mg}(0.16 \mathrm{mmol})$ of $\left[\left(\mathrm{FcC} \equiv \mathrm{CPh}_{2} \mathrm{P}\right)_{2} \mathrm{PtCl}_{2}\right]$ (3a) and $67 \mathrm{mg}$ $(0.32 \mathrm{mmol})$ of ethynylferrocene (4a) dissolved in $40 \mathrm{~mL}$ of diisopropylamine was added $1 \mathrm{mg}$ of [CuI]. After 1 day of stirring, all volatiles were removed in oil-pump vacuum and the orange residue was chromatographed on alumina with dichloromethane/n-hexane (1:1, vs/vs) as eluent. Complex 6 was isolated as an orange solid. Yield: $170 \mathrm{mg}(0.12 \mathrm{mmol}, 75 \%$ based on $3 \mathrm{a})$.

Anal. Calc. for $\mathrm{C}_{72} \mathrm{H}_{56} \mathrm{Fe}_{4} \mathrm{P}_{2} \mathrm{Pt} \times 1 / 3 \mathrm{CH}_{2} \mathrm{Cl}_{2}$ (1427.10): $\mathrm{C}, 60.76 ; \mathrm{H}$, 3.99. Found: C, $60.79 ; \mathrm{H}, 4.15 \%$. M.p.: $198^{\circ} \mathrm{C}$ (decomp.). IR ( $\mathrm{KBr}$, $\left.\mathrm{cm}^{-1}\right): 2180\left(\mathrm{~m}, v_{\mathrm{PtC} \equiv \mathrm{c}}\right), 2162\left(\mathrm{~m}, v_{\mathrm{PC}=\mathrm{C}}\right) .{ }^{1} \mathrm{H} \mathrm{NMR}\left(\delta, \mathrm{CDCl}_{3}\right)$ : $3.81\left(\mathrm{pt}, J_{\mathrm{HH}}=1.7 \mathrm{~Hz}, 4 \mathrm{H}, H^{\beta} \mathrm{C}_{5} \mathrm{H}_{4} / \mathrm{FCC} \equiv \mathrm{CPt}\right), 3.84\left(\mathrm{~s}, 10 \mathrm{H}, \mathrm{C}_{5} \mathrm{H}_{5} /\right.$ $\mathrm{FcC} \equiv \mathrm{CPt}), 3.86\left(\mathrm{pt}, J_{\mathrm{HH}}=1.7 \mathrm{~Hz}, 4 \mathrm{H}, H^{\alpha} \mathrm{C}_{5} \mathrm{H}_{4} / \mathrm{FcC} \equiv \mathrm{CPt}\right), 4.19(\mathrm{~s}$, $\left.10 \mathrm{H}, \mathrm{C}_{5} \mathrm{H}_{5} / \mathrm{FcC} \equiv \mathrm{CP}\right), 4.23\left(\mathrm{pt}, J_{\mathrm{HH}}=1.9 \mathrm{~Hz}, 4 \mathrm{H}, H^{\beta} / \mathrm{C}_{5} \mathrm{H}_{4} / \mathrm{FcC} \equiv \mathrm{CP}\right)$, $4.55\left(\mathrm{pt}, J_{\mathrm{HH}}=1.9 \mathrm{~Hz}, 4 \mathrm{H}, H^{\alpha} / \mathrm{C}_{5} \mathrm{H}_{4} / \mathrm{FCC} \equiv \mathrm{CP}\right), 5.29\left(\mathrm{~s}, \mathrm{CH}_{2} \mathrm{Cl}_{2}\right)$, 7.44-7.50 (m, 12H, $\left.\mathrm{C}_{6} \mathrm{H}_{5}\right), 8.08-8.19\left(\mathrm{~m}, 8 \mathrm{H}, \mathrm{C}_{6} \mathrm{H}_{5}\right) .{ }^{31} \mathrm{P}\left\{{ }^{1} \mathrm{H}\right\} \mathrm{NMR}$ $\left(\delta, \mathrm{CDCl}_{3}\right):-7.3\left(J_{31_{\mathrm{p}} 195_{\mathrm{pt}}}=2765\right)$.

\subsection{Synthesis of $(\mathrm{FCC} \equiv \mathrm{C})_{3} \mathrm{P}=\mathrm{O}(\mathbf{6})$}

Through a solution of $40 \mathrm{~mL}$ tetrahydrofuran containing $100 \mathrm{mg}$ $(0.15 \mathrm{mmol})$ of $(\mathrm{FCC} \equiv \mathrm{C})_{3} \mathrm{P}(1 \mathrm{c})$ was bubbled air for $1 \mathrm{~h}$ at $40^{\circ} \mathrm{C}$. After evaporation of the solvent in oil-pump vacuum, the title compound was obtained as a red-orange solid. Yield: $101 \mathrm{mg}$ $(0.15 \mathrm{mmol}, 99 \%$ based on $1 \mathrm{c})$. 
Anal. Calc. for $\mathrm{C}_{36} \mathrm{H}_{27} \mathrm{Fe}_{3} \mathrm{PO}$ (673.99): C, 64.10; $\mathrm{H}, 4.04$. Found: $\mathrm{C}$, 64.14; H, 4.23\%. M.p.: $178{ }^{\circ} \mathrm{C}$ (decomp.). IR ( $\mathrm{KBr}, \mathrm{cm}^{-1}$ ): 2151 (s, $\left.v_{\mathrm{C}} \equiv \mathrm{c}\right), 1254\left(\mathrm{w}, v_{\mathrm{P}=0}\right) .{ }^{1} \mathrm{H}$ NMR $\left(\delta, \mathrm{CDCl}_{3}\right): 4.32\left(\mathrm{~s}, 15 \mathrm{H}, \mathrm{C}_{5} \mathrm{H}_{5}\right)$, $4.34\left(\mathrm{pt}, J_{\mathrm{HH}}=1.7 \mathrm{~Hz}, 6 \mathrm{H}, H^{\beta} / \mathrm{C}_{5} \mathrm{H}_{4}\right), 4.65\left(\mathrm{pt}, J_{\mathrm{HH}}=1.7 \mathrm{~Hz}, 6 \mathrm{H}, H^{\alpha}\right)$ $\left.\mathrm{C}_{5} \mathrm{H}_{4}\right) .{ }^{13} \mathrm{C}\left\{{ }^{1} \mathrm{H}\right\}$ NMR $\left(\delta, \mathrm{CDCl}_{3}\right): 62.3\left(\mathrm{C}^{i} / \mathrm{C}_{5} \mathrm{H}_{4}\right), 70.5\left(\mathrm{C}^{\beta} / \mathrm{C}_{5} \mathrm{H}_{4}\right)$, $70.7\left(\mathrm{C}_{5} \mathrm{H}_{5}\right), 72.8\left(C^{\alpha} / \mathrm{C}_{5} \mathrm{H}_{4}\right), 109.7(\mathrm{C} \equiv \mathrm{C}) .{ }^{31} \mathrm{P}\left\{{ }^{1} \mathrm{H}\right\} \mathrm{NMR}\left(\delta, \mathrm{CDCl}_{3}\right)$ : -66.8 .

\subsection{Synthesis of $\left[(\mathrm{FCC} \equiv \mathrm{C}) \mathrm{Ph}_{2} P A u C l\right](8 \boldsymbol{a})$}

To a tetrahydrofuran solution ( $30 \mathrm{~mL}$ ) containing $240 \mathrm{mg}$ $(0.75 \mathrm{mmol})$ of [(tht)AuCl] (7) was added dropwise a solution with $283 \mathrm{mg}(1.132 \mathrm{mmol})$ of $(\mathrm{FcC} \equiv \mathrm{C}) \mathrm{Ph}_{2} \mathrm{P}(1 \mathrm{a})$ in $30 \mathrm{~mL}$ of tetrahydrofuran over a period of $1 \mathrm{~h}$ at $0{ }^{\circ} \mathrm{C}$. After $1 \mathrm{~h}$ of stirring at $25^{\circ} \mathrm{C}$, all volatiles were removed in oil-pump vacuum. The title compound was chromatographed on silica gel with diethyl ether as eluent. Compound $\mathbf{8 a}$ was isolated as an orange solid. Yield: $350 \mathrm{mg}$ ( $0.73 \mathrm{mmol}, 97 \%$ based on 7 ).

Anal. Calc. for $\mathrm{C}_{24} \mathrm{H}_{19} \mathrm{AuClFeP}$ (625.99): C, 46.01; $\mathrm{H}, 3.06$. Found: C, $45.97 ; \mathrm{H}, 3.17 \%$. M.p.: $181^{\circ} \mathrm{C}$ (decomp.). IR $\left(\mathrm{KBr}, \mathrm{cm}^{-1}\right): 2158$ (s, $\left.v_{\mathrm{C}}=\mathrm{C}\right) .{ }^{1} \mathrm{H}$ NMR $\left(\delta, \mathrm{CDCl}_{3}\right): 4.25\left(\mathrm{~s}, 5 \mathrm{H}, \mathrm{C}_{5} \mathrm{H}_{5}\right), 4.37\left(\mathrm{pt}, J_{\mathrm{HH}}=1.9 \mathrm{~Hz}\right.$, $\left.2 \mathrm{H}, H^{\beta} / \mathrm{C}_{5} \mathrm{H}_{4}\right), 4.63\left(\mathrm{pt}, J_{\mathrm{HH}}=1.9 \mathrm{~Hz}, 2 \mathrm{H}, H^{\alpha} / \mathrm{C}_{5} \mathrm{H}_{4}\right), 7.44-7.58(\mathrm{~m}, 6 \mathrm{H}$, $\left.\mathrm{C}_{6} \mathrm{H}_{5}\right), 7.75-7.88\left(\mathrm{~m}, 4 \mathrm{H}, \mathrm{C}_{6} \mathrm{H}_{5}\right) .{ }^{13} \mathrm{C}\left\{{ }^{1} \mathrm{H}\right\}$ NMR $\left(\delta, \mathrm{CDCl}_{3}\right): 60.6$ (d, $\left.J_{\mathrm{CP}}=3.8 \mathrm{~Hz}, \quad C^{i} / \mathrm{C}_{5} \mathrm{H}_{4}\right), \quad 70.6 \quad\left(\mathrm{C}_{5} \mathrm{H}_{5}\right), 70.6 \quad\left(\mathrm{C}^{\beta} / \mathrm{C}_{5} \mathrm{H}_{4}\right), 72.8 \quad(\mathrm{~d}$, $\left.J_{\mathrm{CP}}=1.4 \mathrm{~Hz}, \quad C^{\alpha} / \mathrm{C}_{5} \mathrm{H}_{4}\right), 112.5\left(\mathrm{~d}, J_{\mathrm{CP}}=22.8 \mathrm{~Hz}, \mathrm{C} \equiv \mathrm{C}\right), 129.4(\mathrm{~d}$, $\left.J_{\mathrm{CP}}=13.0 \mathrm{~Hz}, \mathrm{C}^{m} / \mathrm{C}_{6} \mathrm{H}_{5}\right), 129.8\left(\mathrm{~d}, J_{\mathrm{CP}}=71.0 \mathrm{~Hz}, \mathrm{C}^{i} / \mathrm{C}_{6} \mathrm{H}_{5}\right), 132.2(\mathrm{~d}$, $\left.J_{\mathrm{CP}}=2.9 \mathrm{~Hz}, \quad C^{p} / \mathrm{C}_{6} \mathrm{H}_{5}\right), 133.0\left(\mathrm{~d}, J_{\mathrm{CP}}=15.8 \mathrm{~Hz}, \quad C^{\circ} / \mathrm{C}_{6} \mathrm{H}_{5}\right) .{ }^{31} \mathrm{P}\left\{{ }^{1} \mathrm{H}\right\}$ $\operatorname{NMR}\left(\delta, \mathrm{CDCl}_{3}\right): 1.9$.

\subsection{Synthesis of $\left[\left((\mathrm{FCC} \equiv \mathrm{C})_{2} \mathrm{PhP}\right) \mathrm{AuCl}\right](\boldsymbol{8} \boldsymbol{b})$}

To a tetrahydrofuran solution (30 mL) containing $526 \mathrm{mg}$ $(1.00 \mathrm{mmol})$ of $(\mathrm{FcC} \equiv \mathrm{C})_{2} \mathrm{PhP}(\mathbf{1 b})$ in $30 \mathrm{~mL}$ were added $240 \mathrm{mg}$ $(0.75 \mathrm{mmol})$ of [(tht)AuCl] (7) dissolved in $30 \mathrm{~mL}$ of tetrahydro- furan over a period of $1 \mathrm{~h}$ at $0^{\circ} \mathrm{C}$. After appropriate work-up (see 8a), the title compound was column chromatographed on silica gel using diethyl ether as eluent. Complex $\mathbf{8 b}$ could be obtained as an orange solid. Yield: $486 \mathrm{mg}(0.64 \mathrm{mmol}, 86 \%$ based on 7).

Anal. Calc. for $\mathrm{C}_{30} \mathrm{H}_{23} \mathrm{AuClFe}_{2} \mathrm{P}$ (757.96): C, 47.50; $\mathrm{H}, 3.06$. Found: C, $47.80 ; \mathrm{H}, 3.21 \%$. M.p.: $93^{\circ} \mathrm{C}$. IR $\left(\mathrm{KBr}, \mathrm{cm}^{-1}\right)$ : 2154 (s, $v_{\mathrm{C} \equiv \mathrm{C}) .}{ }^{1} \mathrm{H} \operatorname{NMR}\left(\delta, \mathrm{CDCl}_{3}\right): 4.26\left(\mathrm{~s}, 10 \mathrm{H}, \mathrm{C}_{5} \mathrm{H}_{5}\right), 4.33\left(\mathrm{pt}, J_{\mathrm{HH}}=1.9 \mathrm{~Hz}\right.$, $\left.4 \mathrm{H}, H^{\beta} / \mathrm{C}_{5} \mathrm{H}_{4}\right), 4.59\left(\mathrm{pt}, J_{\mathrm{HH}}=1.6 \mathrm{~Hz}, 4 \mathrm{H}, H^{\alpha} / \mathrm{C}_{5} \mathrm{H}_{4}\right), 7.50-7.58(\mathrm{~m}, 3 \mathrm{H}$, $\left.\mathrm{C}_{6} \mathrm{H}_{5}\right), 7.91-8.03\left(\mathrm{~m}, 2 \mathrm{H}, \mathrm{C}_{6} \mathrm{H}_{5}\right) \cdot{ }^{13} \mathrm{C}\left\{{ }^{1} \mathrm{H}\right\} \operatorname{NMR}\left(\delta, \mathrm{CDCl}_{3}\right): 61.2(\mathrm{~d}$, $\left.J_{\mathrm{CP}}=2.9 \mathrm{~Hz}, \quad C / \mathrm{C}_{5} \mathrm{H}_{4}\right), \quad 70.4 \quad\left(C^{\beta} / \mathrm{C}_{5} \mathrm{H}_{4}\right), \quad 70.5 \quad\left(\mathrm{C}_{5} \mathrm{H}_{5}\right), 72.7 \quad(\mathrm{~d}$, $\left.J_{\mathrm{CP}}=4.8 \mathrm{~Hz}, \mathrm{C}^{\alpha} / \mathrm{C}_{5} \mathrm{H}_{4}\right), 75.4(\mathrm{C} \equiv \mathrm{C}), 109.2\left(\mathrm{~d}, J_{\mathrm{CP}}=24.3 \mathrm{~Hz}, \mathrm{C} \equiv \mathrm{C}\right)$, $129.4\left(\mathrm{~d}, J_{\mathrm{CP}}=12.8 \mathrm{~Hz}, \mathrm{C}^{m} / \mathrm{C}_{6} \mathrm{H}_{5}\right), 129.5\left(C^{i} / \mathrm{C}_{6} \mathrm{H}_{5}\right), 131.8\left(C^{p} / \mathrm{C}_{6} \mathrm{H}_{5}\right)$, $132.4\left(\mathrm{~d}, J_{\mathrm{CP}}=18.3 \mathrm{~Hz}, \mathrm{C}^{\circ} / \mathrm{C}_{6} \mathrm{H}_{5}\right) .{ }^{31} \mathrm{P}\left\{{ }^{1} \mathrm{H}\right\} \operatorname{NMR}\left(\delta, \mathrm{CDCl}_{3}\right):-37.5$.

\subsection{Synthesis of $\left[\left((F C C \equiv C) P h_{2} P\right) A u C \equiv C F c\right](9 a)$}

To a diethylamine solution $(50 \mathrm{~mL})$ containing $150 \mathrm{mg}$ $(0.24 \mathrm{mmol})$ of $\left[\left((\mathrm{FcC} \equiv \mathrm{C}) \mathrm{Ph}_{2} \mathrm{P}\right) \mathrm{AuCl}\right](8 \mathrm{a})$ and $60 \mathrm{mg}(0.29 \mathrm{mmol})$ of ethynylferrocene was added $1 \mathrm{mg}$ of [CuI]. After $2 \mathrm{~h}$ stirring at $25{ }^{\circ} \mathrm{C}$ all volatiles were removed in oil-pump vacuum and 9a was purified by chromatography on silica gel with a hexane/diethyl ether mixture (1:4, vs/vs) as eluent. Yield: $160 \mathrm{mg}(0.20 \mathrm{mmol}$, $84 \%$ based on 8 a).

Anal. Calc. for $\mathrm{C}_{36} \mathrm{H}_{28} \mathrm{AuFe}_{2} \mathrm{P}$ (800.03): C, 54.00; H, 3.53. Found:

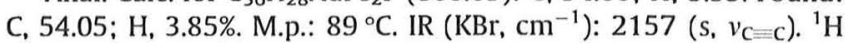
$\operatorname{NMR}\left(\delta, \mathrm{CDCl}_{3}\right): 4.13\left(\mathrm{pt}, J_{\mathrm{HH}}=1.9 \mathrm{~Hz}, 2 \mathrm{H}, H^{\beta} / \mathrm{AuC} \equiv \mathrm{CFC}\right), 4.22(\mathrm{~s}$, $\left.5 \mathrm{H}, \quad \mathrm{C}_{5} \mathrm{H}_{5} / \mathrm{AuC} \equiv \mathrm{CFc}\right), 4.25\left(\mathrm{~s}, 5 \mathrm{H}, \quad \mathrm{C}_{5} \mathrm{H}_{5} / \mathrm{PC} \equiv \mathrm{CFC}\right), 4.35 \quad(\mathrm{pt}$, $\left.J_{\mathrm{HH}}=1.9 \mathrm{~Hz}, 2 \mathrm{H}, H^{\beta} / \mathrm{PC} \equiv \mathrm{CFc}\right), 4.46\left(\mathrm{pt}, J_{\mathrm{HH}}=1.9 \mathrm{~Hz}, 2 \mathrm{H}, H^{\alpha} /\right.$ $\mathrm{AuC} \equiv \mathrm{CFc}), 4.61\left(\mathrm{pt}, J_{\mathrm{HH}}=1.9 \mathrm{~Hz}, 2 \mathrm{H}, H^{\alpha} / \mathrm{PC} \equiv \mathrm{CFc}\right), 7.42-7.54(\mathrm{~m}$, $\left.6 \mathrm{H}, \mathrm{C}_{6} \mathrm{H}_{5}\right), 7.77-7.90\left(\mathrm{~m}, 4 \mathrm{H}, \mathrm{C}_{6} \mathrm{H}_{5}\right) .{ }^{13} \mathrm{C}\left\{{ }^{1} \mathrm{H}\right\}$ NMR $\left(\delta, \mathrm{CDCl}_{3}\right): 61.1$ $\left(\mathrm{d}, J_{\mathrm{CP}}=3.0 \mathrm{~Hz}, \mathrm{C}^{i} / \mathrm{C}_{5} \mathrm{H}_{4} / \mathrm{PC} \equiv \mathrm{CFc}\right), 67.4\left(\mathrm{C}^{i} / \mathrm{C}_{5} \mathrm{H}_{4} / \mathrm{AuC} \equiv \mathrm{CFC}\right), 68.0$ $\left(\mathrm{C}_{5} \mathrm{H}_{4} / \mathrm{AuC} \equiv \mathrm{CFC}\right), 70.2\left(\mathrm{C}_{5} \mathrm{H}_{5} / \mathrm{AuC} \equiv \mathrm{CFC}\right), 70.4\left(\mathrm{C}_{5} \mathrm{H}_{4} / \mathrm{AuC} \equiv \mathrm{CFC}\right)$,

Table 6

Crystal and Intensity Collection Data for 3c, 5 and $\mathbf{6 .}$

\begin{tabular}{|c|c|c|c|}
\hline & 3c & 5 & 6 \\
\hline Formula weight & 1709.57 & 1486.52 & 674.10 \\
\hline Chemical formula & $\mathrm{C}_{72} \mathrm{H}_{54} \mathrm{Cl}_{2} \mathrm{Fe}_{6} \mathrm{P}_{2} \mathrm{Pt} 1.5 \mathrm{CH}_{2} \mathrm{Cl}_{2}$ & $\mathrm{C}_{72} \mathrm{H}_{56} \mathrm{Fe}_{4} \mathrm{P}_{2} \mathrm{Pt} \mathrm{CH}_{2} \mathrm{Cl}_{2}$ & $\mathrm{C}_{36} \mathrm{H}_{27} \mathrm{Fe}_{3} \mathrm{OP}$ \\
\hline Crystal system & Triclinic & Triclinic & Monoclinic \\
\hline Space group & P1 & $\mathrm{Pi}$ & $P 2_{1} / \mathrm{c}$ \\
\hline$a(A)$ & $12.9786(10)$ & $8.1907(6)$ & $12.5325(7)$ \\
\hline$b(\AA)$ & $15.7926(11)$ & $11.9938(7)$ & $11.9733(8)$ \\
\hline$c(\AA)$ & $16.5193(15)$ & $16.4187(10)$ & $18.7893(15)$ \\
\hline$\alpha\left({ }^{\circ}\right)$ & $96.071(7)$ & $72.625(5)$ & \\
\hline$\beta\left({ }^{\circ}\right)$ & $106.794(7)$ & $79.284(6)$ & $103.321(6)$ \\
\hline$y\left({ }^{\circ}\right)$ & $96.893(6)$ & $74.838(6)$ & \\
\hline$V\left(\AA^{3}\right)$ & $3182.7(4)$ & $1475.54(16)$ & $2743.6(3)$ \\
\hline$\rho_{\text {calc }}\left(\mathrm{g} \mathrm{cm}^{-3}\right)$ & 1.784 & 1.673 & 1.632 \\
\hline$F(000)$ & 1694 & 742 & 1376 \\
\hline Crystal dimensions ( $\mathrm{mm}$ ) & $0.05 \times 0.02 \times 0.02$ & $0.4 \times 0.1 \times 0.02$ & $0.3 \times 0.1 \times 0.1$ \\
\hline$z$ & 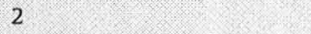 & 1 & $4-2=12$ \\
\hline Maximum and minimum Transmission & $1.00000,0.86690$ & $1.00000,0.84829$ & $1.01231,0.98667$ \\
\hline Absorption coefficient $\left(\lambda, \mathrm{mm}^{-1}\right)$ & 3.823 & 3.511 & 1.654 \\
\hline Scan range $\left({ }^{\circ}\right)$ & $2.88-26.07$ & $3.28-26.06$ & $2.99-26.00$ \\
\hline Index ranges & $\begin{array}{l}-16 \leq h \leq 16,-19 \leq k \leq 19 \\
-20 \leq l \leq 20\end{array}$ & $\begin{array}{l}-10 \leq h \leq 10,-14 \leq k \leq 14 . \\
-20 \leq l \leq 20\end{array}$ & $\begin{array}{l}-15 \leq h \leq 15,-14 \leq k \leq 14 . \\
-23 \leq l \leq 23\end{array}$ \\
\hline Total reflections & 31935 & 14372 & 26684 \\
\hline Unique reflections & 12570 & 5783 & 5393 \\
\hline$R_{\text {int }}$ & 0.0438 & 0.0388 & 0.0229 \\
\hline Data/restraints/parameters & $12570 / 0 / 793$ & $5783 / 12 / 397$ & $5393 / 0 / 370$ \\
\hline Goodness-of-fit on $F^{2}$ & 0.933 & 0.977 & 1.032 \\
\hline$R_{1}{ }^{\mathrm{d}}, w R_{2}{ }^{\mathrm{a}} \|[2 \sigma(I)]$ & $0.0310,0.0507$ & $0.0288,0.0528$ & $0.0221,0.0585$ \\
\hline$R_{1}{ }^{a}, w R_{2}^{a}$ (all data) & $0.0551,0.0573$ & $0.0416,0.0580$ & $0.0282,0.0602$ \\
\hline Largest difference peak and hole $\left(\mathrm{e} \AA^{-3}\right)$ & $1.802,-1.298$ & $1.295,-0.848$ & $0.357,-0.499$ \\
\hline
\end{tabular}

\footnotetext{
${ }^{\mathrm{a}} R_{1}=\left[\Sigma\left(|| F_{\mathrm{o}}|-| F_{\mathrm{c}} \mid\right) / \Sigma\left|F_{\mathrm{o}}\right|\right) ; w R_{2}=\left[\Sigma\left(w\left(F_{\mathrm{o}}^{2}-F_{\mathrm{c}}^{2}\right)^{2}\right) / \Sigma\left(w F_{\mathrm{o}}^{4}\right)\right]^{1 / 2} \cdot S=\left[\Sigma w\left(F_{\mathrm{o}}^{2}-F_{\mathrm{c}}^{2}\right)^{2}\right] /(n-p)^{1 / 2} \cdot n=$ number of reflections, $p=$ parameters used.
} 
Table 7

Crystal and intensity collection data for $\mathbf{8 a}, \mathbf{9 a}$, and $\mathbf{9 b}$.

\begin{tabular}{|c|c|c|c|}
\hline & $8 a$ & $9 a$ & $9 \mathbf{b}$ \\
\hline Formula weight & 626.63 & 800.22 & 905.12 \\
\hline Chemical formula & $\mathrm{C}_{24} \mathrm{H}_{19} \mathrm{AuCIFeP}$ & $\mathrm{C}_{36} \mathrm{H}_{28} \mathrm{AuFe}_{2} \mathrm{P}$ & $\mathrm{C}_{36} \mathrm{H}_{28}$ AuFePRu $0.5 \mathrm{CHCl}_{3}$ \\
\hline Crystal system & Monoclinic & Monoclinic & Monoclinic \\
\hline Space group & $P 2_{1} / n$ & $P 2_{1} / c$ & $P 2_{1} / a$ \\
\hline$a(A)$ & $9.9198(7)$ & $15.3726(17)$ & $13.7289(10)$ \\
\hline$b(A)$ & $19.1756(15)$ & $7.5512(5)$ & $18.3090(13)$ \\
\hline$c(A)$ & $12.0771(9)$ & $24.927(3)$ & $14.4577(8)$ \\
\hline$\beta\left(0^{\circ}\right)$ & $113.071(7)$ & $106.505(10)$ & $114.223(6)$ \\
\hline$V\left(\AA^{3}\right)$ & $2113.5(3)$ & $2774.3(5)$ & $3314.2(4)$ \\
\hline$\rho_{\text {calc }}\left(\mathrm{g} \mathrm{cm}^{-3}\right)$ & 1.969 & 1.916 & 1.814 \\
\hline$F(000)$ & 1200 & 1560 & 1748 \\
\hline Crystal dimensions ( $\mathrm{mm}$ ) & $0.5 \times 0.2 \times 0.1$ & $0.5 \times 0.2 \times 0.1$ & $0.3 \times 0.2 \times 0.05$ \\
\hline$z$ & 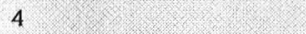 & 4 & 4 \\
\hline Maximum and minimum Transmission & $1.47670,0.34621$ & $1.19314,0.68665$ & $1.00000,0.46972$ \\
\hline Absorption coefficient $\left(\lambda, \mathrm{mm}^{-1}\right)$ & 7.829 & 6.390 & 5.491 \\
\hline Scan range $\left({ }^{\circ}\right)$ & $3.08-26.08$ & $4.90-25.50$ & $2.97-26.09$ \\
\hline Index ranges & $\begin{array}{l}-12 \leq h \leq 12,-23 \leq k \leq 23 \\
-14 \leq l \leq 14\end{array}$ & $-18 \leq h \leq 18,-8 \leq k \leq 9,-30 \leq l \leq 30$ & $\begin{array}{l}-16 \leq h \leq 16,-22 \leq k \leq 22, \\
-17 \leq l \leq 17\end{array}$ \\
\hline Total reflections & 20397 & 17054 & 32220 \\
\hline$R_{\text {int }}$ & 0.0286 & 0.0276 & 0.0349 \\
\hline Data/restraints/parameters & $4171 / 0 / 253$ & $5026 / 15 / 361$ & $6536 / 41 / 394$ \\
\hline Goodness-of-fit on $F^{2}$ & 1.055 & 1.045 & 1.102 \\
\hline$R_{1}^{a}, w R_{2}^{a}[I 2 \sigma(I)]$ & $0.0165,0.0384$ & $0.0258,0.0598$ & $0.0384,0.1090$ \\
\hline$R_{1}^{a}, w R_{2}^{a}$ (all data) & $0.0216,0.0393$ & $0.0299,0.0610$ & $0.0548,0.1152$ \\
\hline Largest difference peak and hole (e $\AA^{-3}$ ) & $0.848,-0.727$ & $3.073,-1.151$ & $3.845,-1.583$ \\
\hline
\end{tabular}

${ }^{\mathrm{a}} R_{1}=\left[\Sigma\left(|| F_{\mathrm{o}}|-| F_{\mathrm{c}} \mid\right) / \Sigma\left|F_{\mathrm{o}}\right|\right) ; w \mathrm{R}_{2}=\left[\Sigma\left(w\left(F_{0}^{2}-F_{\mathrm{c}}^{2}\right)^{2}\right) / \Sigma\left(w F_{\mathrm{o}}^{4}\right)\right]^{1 / 2} \cdot S=\left[\Sigma w\left(F_{0}^{2}-F_{\mathrm{c}}^{2}\right)^{2}\right] /(n-p)^{1 / 2} \cdot n=$ number of reflections, $p=$ parameters used.

$70.5\left(\mathrm{C}_{5} \mathrm{H}_{5} / \mathrm{PC} \equiv \mathrm{CFc}\right), 72.0\left(C^{\beta} \mathrm{C}_{5} \mathrm{H}_{4} / \mathrm{PC} \equiv \mathrm{CFc}\right), 72.7\left(\mathrm{~d}, J_{\mathrm{CP}}=1.0 \mathrm{~Hz}\right.$, $\left.C^{\alpha} / \mathrm{C}_{5} \mathrm{H}_{4} / \mathrm{PC} \equiv \mathrm{CFc}\right), 129.3\left(\mathrm{~d}, J_{\mathrm{CP}}=12.5 \mathrm{~Hz}, C^{m} / \mathrm{C}_{6} \mathrm{H}_{5}\right), 130.8$ (d, $\left.J_{\mathrm{CP}}=63.3 \mathrm{~Hz}, C^{i} / \mathrm{C}_{6} \mathrm{H}_{5}\right), 131.8\left(\mathrm{~d}, J_{\mathrm{CP}}=2.4 \mathrm{~Hz}, C^{p} / \mathrm{C}_{6} \mathrm{H}_{5}\right), 133.2(\mathrm{~d}$, $\left.J_{\mathrm{CP}}=15.8 \mathrm{~Hz}, \mathrm{C}^{\circ} / \mathrm{C}_{6} \mathrm{H}_{5}\right) \cdot{ }^{31} \mathrm{P}\left\{{ }^{1} \mathrm{H}\right\} \mathrm{NMR}\left(\delta, \mathrm{CDCl}_{3}\right): 15.1$.

\subsection{Synthesis of $\left[\left((F c C \equiv C) P h_{2} P\right) A u C \equiv C R c\right](9 \boldsymbol{b})$}

Complex $\mathbf{9 b}$ was synthesized in a similar manner as discussed for 9a: $150 \mathrm{mg}(0.24 \mathrm{mmol})$ of $\left[\left((\mathrm{FcC} \equiv \mathrm{C}) \mathrm{Ph}_{2} \mathrm{P}\right) \mathrm{AuCl}\right](8)$ were reacted with $80 \mathrm{mg}(0.31 \mathrm{mmol})$ of ethynyl ruthenocene at $50^{\circ} \mathrm{C}$. After appropriate work-up, compound $\mathbf{9 b}$ was isolated as an orange-yellow solid. Yield: $180 \mathrm{mg}$ ( $0.21 \mathrm{mmol}, 89 \%)$.

Anal. Calc. for $\mathrm{C}_{36} \mathrm{H}_{28} \mathrm{AuFePRu} \times \mathrm{CH}_{2} \mathrm{Cl}_{2}$ (930.93): $\mathrm{C}$, 47.74; $\mathrm{H}$, 3.25. Found: C, 48.18 ; H, 3.25\%. M.p.: $95^{\circ} \mathrm{C}$. IR $\left(\mathrm{KBr}, \mathrm{cm}^{-1}\right): 2167$ $\left(\mathrm{s}, v_{\mathrm{C}=\mathrm{C}}\right) .{ }^{1} \mathrm{H}$ NMR $\left(\delta, \mathrm{CDCl}_{3}\right): 4.24\left(\mathrm{~s}, 5 \mathrm{H}, \mathrm{C}_{5} \mathrm{H}_{5} / \mathrm{Fc}\right), 4.35$ (pt, $J_{\mathrm{HH}}=1.7 \mathrm{~Hz}, 2 \mathrm{H}, H^{\beta} / \mathrm{Fc}$ ), $4.49\left(\mathrm{pt}, J_{\mathrm{HH}}=1.7 \mathrm{~Hz}, 2 \mathrm{H}, H^{\beta} / \mathrm{Rc}\right), 4.59-$ $4.61\left(\mathrm{~m}, 2 \mathrm{H}, H^{\alpha} / \mathrm{Fc} ; 5 \mathrm{H}, \mathrm{C}_{5} \mathrm{H}_{5} / \mathrm{Rc}\right), 4.88\left(\mathrm{pt}, J_{\mathrm{HH}}=1.7 \mathrm{~Hz}, 2 \mathrm{H}, H^{\alpha}\right)$ Rc), $5.29\left(\mathrm{CH}_{2} \mathrm{Cl}_{2}\right) 7.41-7.56\left(\mathrm{~m}, 6 \mathrm{H}, \mathrm{C}_{6} \mathrm{H}_{5}\right), 7.76-7.88(\mathrm{~m}, 4 \mathrm{H}$, $\left.\mathrm{C}_{6} \mathrm{H}_{5}\right),{ }^{13} \mathrm{C}\left\{{ }^{1} \mathrm{H}\right\}$ NMR $\left(\delta, \mathrm{CDCl}_{3}\right): 70.0\left(\mathrm{C}_{5} \mathrm{H}_{4} / \mathrm{Rc}\right), 70.4\left(C^{\beta} \mathrm{C}_{5} \mathrm{H}_{4} / \mathrm{Fc}\right)$, $70.5\left(\mathrm{C}_{5} \mathrm{H}_{5} / \mathrm{Fc}\right), 71.9\left(\mathrm{C}_{5} \mathrm{H}_{5} / \mathrm{Rc}\right), 72.7\left(\mathrm{~d}, J_{\mathrm{CP}}=1.0 \mathrm{~Hz}, C^{\alpha} / \mathrm{C}_{5} \mathrm{H}_{4} / \mathrm{Fc}\right)$, $74.4\left(\mathrm{C}_{5} \mathrm{H}_{4} / \mathrm{Rc}\right), 129.3\left(\mathrm{~d}, J_{\mathrm{CP}}=12.5 \mathrm{~Hz}, C^{m} / \mathrm{C}_{6} \mathrm{H}_{5}\right), 130.8$ (d, $\left.J_{\mathrm{CP}}=64.3 \mathrm{~Hz}, C^{i} / \mathrm{C}_{6} \mathrm{H}_{5}\right), 131.8\left(C^{p} / \mathrm{C}_{6} \mathrm{H}_{5}\right), 133.2\left(\mathrm{~d}, J_{\mathrm{CP}}=15.4 \mathrm{~Hz}, \mathrm{C}^{\circ} /\right.$ $\left.\mathrm{C}_{6} \mathrm{H}_{5}\right) \cdot{ }^{31} \mathrm{P}\left\{{ }^{1} \mathrm{H}\right\} \operatorname{NMR}\left(\delta, \mathrm{CDCl}_{3}\right): 14.9$.

\section{Crystal structure determinations}

Crystal and intensity collection data for $\mathbf{3 c}, \mathbf{5}, \mathbf{6}, \mathbf{8 a}, \mathbf{9 a}$, and $\mathbf{9 b}$ are summarized in Table 6 (3c, 4 , and $\mathbf{6})$ and Table $7(\mathbf{8 a}, \mathbf{9 a}$, and 9b). All data were collected on a Oxford Gemini $S$ diffractometer with graphite monochromatized Mo K $\alpha$ radiation $(\lambda=0.71073 \AA)$ at $100 \mathrm{~K}(\mathbf{4}, 6,8 \mathrm{a}, 9 \mathrm{a}$, and $\mathbf{9 b})$ and $\mathrm{Cu} \mathrm{K} \alpha$ radiation $(\lambda=1.54 \AA)$ at $110 \mathrm{~K}$ (3c) using oil-coated shock-cooled crystals [50]. The structures were solved by direct methods using SHELxs-97 [51] and sIR92 (3c) [53] and refined by full-matrix least-square procedures on $F^{2}$ using SHELxL-97. [52] All non-hydrogen atoms were refined anisotropically and a riding model was employed in the refinement of the hydrogen atom positions.

\section{Supplementary material}

CCDC 697272, 697273, 697271, 697269, 697268 and 697270 contain the supplementary crystallographic data for $\mathbf{3 c}, \mathbf{5}, \mathbf{6}, \mathbf{8 a}$, $\mathbf{9 a}$ and $\mathbf{9 b}$. These data can be obtained free of charge from The Cambridge Crystallographic Data Centre via http://www.ccdc.cam.ac.uk/data_request/cif.

\section{Acknowledgement}

We are grateful to the Deutsche Forschungsgemeinschaft and the Fonds der Chemischen Industrie for financial support. Catharina Meier is acknowledged for fruitful discussions.

\section{References}

[1] (a) M.I. Bruce, P.A. Humphrey, M. Jevric, G.J. Perkins, B.W. Skelton, A.H. White J. Organomet. Chem. 692 (2007) 1748:

(b) J. Durand, S. Gladiali, G. Erre, E. Zangrando, B. Milani, Organometallics 26 (2007) 810;

(c) R.C.J. Atkinson, K. Gerry, V.C. Gibson, N.J. Long. E.L. Marshall, L.J. West, Organometallics 26 (2007) 316:

(d) P. Debroy, S. Roy, Coord. Chem. Rev. 251 (2007) 203;

(e) T.Y. Dong, M. Lin, M.Y.N. Chiang, J.Y. Wu, Organometallics 23 (2004) 3921;

(f) T.Y. Dong, K. Chen, M.C. Lin, L. Lee, Organometallics 24 (2005) 4198;

(g) N.J. Long, Angew. Chem., Int. Ed. 34 (1995) 21:

(h) Special issue, "50th Anniversary of the Discovery of Ferrocene", J. Organomet. Chem. 637-639 (2001), (R.D. Adams, Ed.), and references therein

[2] (a) C.P. Berlinguette, K.R. Dumbar, Chem. Commun. (2005) 2451;

(b) S. Santi, L. Orian, A. Donoli, C. Durante, A. Bisello, P. Ganis, A. Ceccon, Organometallics 26 (2007) 5867;

(c) K. Heinze, S. Reinhardt, Organometallics 26 (2007) 5406;

(d) S. Rabaça, I.C. Santos, M.T. Duarte, V. Gama, Inorg. Chim. Acta 360 (2007) 3855 .

[3] (a) F. Barrière, R.U. Kirss, W.E. Geiger, Organometallics 24 (2005) 48;

(b) A. Shafir, M.P. Power, G.D. Whitener, J. Arnold, Organometallics 19 (2000) 3978:

(c) A. Mendiratta, S. Barlow, M.W. Day, S.R. Marder, Organometallics 18 (1999) 454.

[4] (a) M.I. Bruce, Coord. Chem. Rev. 248 (2004) 1603;

(b) S. Szafert, J.A. Gladysz, Chem. Rev. 106 (2006) PR1;

(c) C. Lapinte, J. Organomet. Chem. 693 (2008) 793;

(d) H. Lang, D.S.A. George, G. Rheinwald, Coord. Chem. Rev. 206-207 (2000) 101; 
(e) P. Low, Annu. Rep. Prog. Chem. Sect. A 102 (2006) 379:

(f) K. Venkatesan, O. Blacque, H. Berke, Dalton Trans. (2007) 1091

(g) H. Lang. R. Packheiser, Collect. Czech. Chem. Commun. 72 (2007) 435:

(h) H. Lang. A. Jakob, Organometallic Chemistry Research Perspectives, in

Richard P. Irwin (Ed.), Nova Science Publishers Inc., 2007, p. 99;

(i) N.J. Long, C.K. Williams, Angew. Chem., Int. Ed. 42 (2003) 2586;

(j) K.-L. Cheung, S.-K. Yip, V.W.-W. Yam, J. Organomet. Chem. 689 (2004) 4451;

(k) K.-C. Cheung, W.-L. Wong, D.-L. Ma, T.-S. Lai, K.-Y. Wong, Coord. Chem. Rev. 251 (2007) 2367;

(I) T.-Y. Dong, M.-C. Lin, M. Y.-N. Chiang, J.-Y. Wu, Organometallics 23 (2004) 3921:

(m) M.P. Cifuentes, M.G. Humphrey, J. Organomet. Chem. 689 (2004) 3968;

(n) B. Bildstein, Coord. Chem. Rev. 206-207 (2000) 369:

(o) R. Packheiser, P. Ecorchard, T. Rüffer, H. Lang, Organometallics 27 (2008)

3534:

(p) T. Baumgartner, R. Réau, Chem. Rev. 106 (2006) 4681;

(q) R. Malacea, E. Manoury, L. Routaboul, J.-C. Daran, R. Poli, J.P. Dunne, A.C.

Withwood, C. Godard, S.B. Duckett, Eur. J. Inorg. Chem. (2006) 1803;

(r) P. Teo, D.M.J. Foo, L.L. Koh, T.S.A. Hor, Dalton Trans. (2004) 3389:

(s) P.M.N. Low, A.L. Tan, T.S.A. Hor, Y.-S. Wen, L.-K. Liu, Organometallics 15 (1996) 2595 .

(t) W. Weigand, C. Robl, Chem. Ber. 126 (1993) 1807.

[5] (a) T. Baumgartner, M. Fiege, F. Pontzen, R. Arteaga-Müller, Organometallics 25 (2006) 5657;

(b) A. Jakob, B. Milde, P. Ecorchard, C. Schreiner, H. Lang, J. Organomet. Chem. (2008). doi: 0.1016/j.jorganchem.2008.09.040;

(c) P. Low. J. Clust. Sci. 19 (2008) 5

[6] (a) G.K. Anderson, H.C. Clark, J.A. Davis, G. Ferguson, M. Parvez, J. Crystallogr. Spectrosc. Res. 12 (1982) 449;

(b) P.M. Van Calcar, M.M. Olmstead, A.L. Balch, Chem. Commun. (1996) 2597; (c) K. Mikami, H. Kakuno, K.A. Kawa, Angew. Chem., Int. Ed. 44 (2005) 7423.

[7] (a) A. Hengefeld, J. Kopf, D. Rehder, Organometallics 2 (1983) 114;

(b) E.C. Constable, C.E. Housecroft, B. Krattinger, M. Neuburger, M. Zehnder, Organometallics 18 (1999) 2565;

(c) D.K. Johnson, T. Rukachaisirikul, Y. Sun, N.J. Taylor, A.J. Canty, A.J. Carty. Inorg. Chem. 32 (1993) 5544.

[8] R. Packheiser, B. Walfort, H. Lang, Oranometallics 25 (2006) 4579.

[9] A.D. Burrows, D.M.P. Mingos, S.E. Lawrence, A.J.P. White, D.J. Williams, J. Chem. Soc., Dalton Trans. (1997) 1295

[10] (a) K. Gagnon, S.M. Aly, A. Brisach-Wittmeyer, D. Bellows, J.-F. Bérubé, I Caron, A.S. Abd-El-Aziz, D. Fortin, P.D. Harvey, Organometallics 27 (2008) 2201;

(b) E. Robé, C. Hegedüs, J. Bakos, Y. Coppel, J.-C. Daran, M. Gouygou, Inorg. Chim. Acta 361 (2008) 1861:

(c) T. Cardolaccia, Y. Li, K.S. Schanze, J. Am. Chem. Soc. 130 (2008) 2535;

(d) A. Sivaramakrishna, B.C.E. Makhubela, F. Zheng. H. Su, G.S. Smith. J.R. Moss, Polyhedron 27 (2008) 44;

(e) J. Forniés, M.A. Gómez-Saso, E. Lallnde, F. Martinez, M.T. Moreno, Organometallics 11 (1992) 2873;

(f) K. Sonogashira, Y. Fujikura, T. Yatake, N. Toyoshima, S. Takahashi, N. Hagihara, J. Organomet. Chem. 145 (1978) 101;

(g) S. Takahashi, Y. Takai, H. Morimoto, K. Sonogashira, N. Hagihara, Mol Cryst. Liq. Cryst. 82 (1982) 139:

(h) K. Sonogashira, T. Yatake, Y. Tohda, S. Takahashi, N. Hagihara, J. Chem. Soc. Chem. Commun. (1977) 291;

(i) K. Sonogashira, S. Takahashi, N. Hagihara, Macromolecules (1977) 879:

(j) I. Collimati, A. Furlani, J. Organomet. Chem. 17 (1969) 457;

(k) R.J. Cross, M.F. Davidson, J. Chem. Soc., Dalton Trans. (1986) 1987.

[11] R.J. Cross, I.G. Phillips, J. Chem. Soc., Dalton Trans. (1982) 2261.

[12] (a) M. Carlsson, B. Eliasson, Organometallics 25 (2006) 5500;

(b) R. D'Amato, A. Furlani, M. Colapietro, G. Portalone, M. Casalboni, M. Falconieri, M.V. Russo, J. Organomet. Chem. 627 (2001) 13

[13] R.F. De Ketellaere, G.P. van der Kelen, J. Mol. Struct. 23 (1974) 233.

[14] (a) G. Bandoli, G. Bortolozzo, D.A. Clemente, U. Croatto, C. Panettoni, J. Chem. Soc. (A) Inorg. Phys. Theor. (1970) 2778;

(b) C.M. Whitaker, K.L. Kott, R.J. McMahon, J. Org. Chem. 60 (1995) 3499.

[15] J. Vicente, M.T. Chicote, M.T. Abrisqueta, J.G. Jones, Organometallics 16 (1997) 5628.

[16] H. Lang, S. Köcher, S. Back, G. Rheinwald, G. van Koten, Organometallics 20 (2001) 1968.

[17] N.C. Baenziger, W.E. Bennett, D.M. Soboroff, Acta Crystallogr. B 32 (1976) 962
[18] (a) K. Rößler, T. Rüffer, B. Walfort, R. Packheiser, R. Holze, M. Zharnikov, H. Lang, J. Organomet. Chem. 692 (2007) 1530;

(b) T.J. Burchell, M.C. Jennings, R.J. Puddephatt, Inorg. Chim. Acta 359 (2006) 2812.

[19] R. Packheiser, A. Jakob, P. Ecorchard, B. Walfort, H. Lang, Organometallics 27 (2008) 1214.

[20] G. Gritzner, J. Kuta, Pure Appl. Chem. 56 (1984) 461.

[21] H. Strehlow, W. Knoche, H. Schneider, Ber. Bunsen. Phys. Chem. 77 (1973) 760

[22] (a) T. Kuwana, D.E. Bublitz, G. Hoh, J. Am. Chem. Soc. 82 (1960) 5811; (b) S.P. Gubin, S.A. Smirnova, L.I. Denisovich, A.A. Lubovich, J. Organomet. Chem. 30 (1971) 243;

(c) S.V. Kukharenko, V.V. Strelets, A.R. Kudinov, A.Z. Kreitlin. M.G. Peterleitner L.I. Denisovich, M.I. Rybinskaya, J. Organomet. Chem. 519 (1996) 1.

[23] (a) Reversible oxidation to the ruthenocenium radical cation and its equilibrium with the dimeric $\left[\mathrm{Cp}_{2} \mathrm{Ru}-\mathrm{RuCp}_{2}\right]^{2+}$ dication has been reported in less nucleophilic environments M.G. Hill, W.M. Lamanna, K.R. Mann, Inorg. Chem. 30 (1991) 4690;

(b) S. Trupia, A. Nafady, W.E. Geiger, Inorg. Chem. 42 (2003) 5480

[24] Instrumental Methods in Electrochemistry, The Southampton Electrochemical Group, Horwood Publishing, Chichester, 2001 (Chapter 6.3.2).

[25] M. Sato, Y. Kubota, Y. Kawata, T. Fujihara, K. Unoura, A. Oyama, Chem. Eur. J. 12 (2006) 2282.

[26] M. Sato, A. Iwai, M. Watanabe, Organometallics 18 (1999) 3208.

[27] M. Sato, Y. Kawata, H. Shintate, Y. Habata, S. Akabori, K. Unoura, Organometallics 16 (1997) 1693.

[28] M. Sato, H. Shintate, Y. Kawata, M. Sekino, M. Katada, S. Kawata, Organometallics 13 (1994) 1956

[29] M.C.B. Colbert, S.L. Ingham, J. Lewis, N.J. Long, P.R. Raithby, J. Chem. Soc. Dalton Trans. (1994) 2215.

[30] M. Sato, E. Mogi, M. Katada, Organometallics 14 (1995) 4837.

[31] S. Back, R.A. Gossage, H. Lang, G. van Koten, Eur. J. Inorg. Chem. (2000) 1457.

[32] M. Sato, Y. Hayashi, H. Shintate, M. Katada, S. Kawata, J. Organomet. Chem. 471 (1994) 179.

[33] N.]. Long, A.J. Martin, A.J.P. White, D.J. Williams, M. Fontani, F. Laschi, P. Zanello, J. Chem. Soc., Dalton Trans. (2000) 3387.

[34] M.C.B. Colbert, J. Lewis, N.J. Long, P.R. Raithby, A.J.P. White. D.J. Williams, J. Chem. Soc., Dalton Trans. (1997) 99.

[35] N.D. Jones, M.O. Wolf, D.M. Giaquinta, Organometallics 16 (1997) 1352

[36] Y. Zhu, O. Clot, M.O. Wolf, G.P.A. Yap, J. Am. Chem. Soc. 120 (1998) 1812.

[37] G. Vives, A. Carella, J.-P. Launay, G. Rapenne, Chem. Commun. (2006) 2283.

[38] (a) D. Osella, O. Gambino, C. Nervi, M. Ravera, M.V. Russo, G. Infante, Inorg. Chim. Acta 225 (1994) 35;

(b) D. Osella, R. Gobetto, C. Nervi, M. Ravera, R. D'Amato, M.V. Russo, Inorg. Chem. Commun. 1 (1998) 239.

[39] M. Sato, Y. Hayashi, S. Kumakura, N. Shimizu, M. Katada, S. Kawata, Organometallics 15 (1996) 721.

[40] C.J. Adams, S.L. James, X. Liu, P.R. Raithby, L.J. Yellowlees, J. Chem. Soc., Dalton Trans. (2000) 63.

[41] M. Ravera, R. D'Amato, A. Guerri, J. Organomet. Chem. 690 (2005) 2376.

[42] E.C. James, M.Jura;G. Kociok-Köhn, P.R. Raithby, E.L. Sharp. P.J. Wilson, Inorg. Chem. 46 (2007) 7232

[43] Y.-J. Chen, S.-S. Chen, S.-S. Lo, T.-H. Huang, C.-C. Wu, G.-H. Lee, S.-M. Peng, C.-Y. Yeh, Chem. Commun. (2006) 1015

[44] S.C. Jones, V. Coropceanu, S. Barlow, T. Kinnibrugh, T. Timofeeva, J.-L. Brédas, S.R. Marder, J. Am. Chem. Soc. 126 (2004) 11782

[45] M. B-Robin, P. Day, Adv. Inorg. Chem. Radiochem. 10 (1967) 247

[46] M. Krejcik, M. Danek, F. Hartl, J. Electroanal. Chem. 317 (1991) 179.

[47] (a) J. Polin, H. Schottenberger, Org. Syn. 73 (1996) 262: (b) M.O. Rausch, A. Siegel, J. Org. Chem. 34 (1969) 1974

[48] H.H. Eysel, E. Guggolz, M. Kopp, M.L. Ziegler, Z. Anorg. Allg. Chem. 499 (1988) 81.

[49] K.C. Dash, H. Schmidbaur, Chem. Ber. 106 (1973) 1221.

[50] (a) T. Kottke, D.J. Stalke, Appl. Crystallogr. 26 (1993) 615;

(b) T. Kottke, R.J. Lagow, D.J. Stalke, Appl. Crystallogr. 29 (1996) 465; (c) D. Stalke, Chem. Soc. Rev. 27 (1998) 171

[51] G.M. Sheldrick, Acta Crystallogr. Sect. A 46 (1990) 467.

[52] A. Altomare, G. Cascarano, C. Giacovazzo, A. Gualardi, J. Appl. Cryst. 26 (1993) 343.

[53] G.M. Sheldrick, SHELXL-97, Program for Crystal Structure Refinement, University of Göttingen, 1997. 